\section{Ankara Üniversitesi Eğitim Bilimleri Fakültesi Özel Eğitim Dergisi}

2021, 22(3), 611-638
ARAŞTIRMA

Gönderim Tarihi: 15.04 .20

Kabul Tarihi: 19.01.21

Erken Görünüm: 31.01.21

\title{
Görme Yetersizliği Olan ve Gören Çocukların Gelişimsel Oyun Seviyeleri ile Zihin Kuramının Karşılaştırmalı İncelenmesi*
}

\author{
Seda Karakaşoğlu iD 1
}

\author{
Selda Özdemir ${ }^{\text {OD } 2}$
}

$\ddot{\mathbf{O}} \mathbf{z}$

Giriş: Bu araştırmada okul öncesi dönemde görme yetersizliği olan ve gören çocukların gelişimsel oyun seviyeleri ile Zihin Kuramı becerileri arasındaki ilişkinin karşılaştırılarak incelenmesi amaçlanmıştır.

Yöntem: Araştırmanın çalışma grubunu, 48-72 ay aralığında olan görme yetersizliği olan 30 çocuk ve aynı ay diliminde olan gören 30 çocuk oluşturmuştur. Katılımcı çocuklar dil ve bilişsel gelişim düzeylerinde de eşleştirilmişlerdir. Araştırmada nedensel karşılaştırma deseni kullanılmıştır. Araştırma kapsamında Gelişimsel Oyun Değerlendirmesi aracılığıyla katılımcı çocukların oyun seviyeleri incelenmiş ve Zihin Kuramı Birinci Derece Yanlış Kanı Atfı görevleri uygulanmıştır.

Bulgular: Araştırma bulguları görme yetersizliği olan ve gören çocukların gelişimsel oyun seviyelerinde iki grup arasında anlamlı farklılıkların olduğunu göstermiştir. Ek olarak araştırmanın bulguları görme yetersizliği olan ve gören çocukların Yanlış Kanı Atfı ve Gelişimsel Oyun Değerlendirmesi puanları arasında anlamlı ilişskiler olduğunu göstermiştir.

Tartışma: Araştırmadan elde edilen bulgular görme becerileri, oyun ve zihin kuramı gelişimini anlama açısından önemlidir. Araştırma bulguları tartışılmış ve ileri araştırmalara yönelik önerilere yer verilmiştir.

Anahtar sözcükler: Görme yetersizliği olan çocuklar, gelişimsel oyun değerlendirmesi, zihin kuramı, birinci derece yanlış kanı atfı, okul öncesi dönemi.

Atıf için: Karakaşoğlu, S., \& Özdemir, S., (2021). Görme yetersizliği olan ve gören çocukların gelişimsel oyun seviyeleri ile zihin kuramının karşılaştırmalı incelenmesi. Ankara Üniversitesi Ĕ̆itim Bilimleri Fakültesi Özel Ĕ̆itim Dergisi, 22(3), 611-638. https://doi.org/10.21565/ozelegitimdergisi.719171

\footnotetext{
*Bu çalışma Prof. Dr. Selda Özdemir'in danışmanlığında gerçekleştirilen Seda Karakaşoğlu'nun yüksek lisans tezinden üretilmiștir.

${ }^{1}$ Sorumlu Yazar: Özel Eğitim Uzman1, İstanbul İl Milli Eğitim Müdürlüğü, E-posta: sedakarakasoglu@gmail.com, https://orcid.org/0000-0002-3477-2389

2Prof. Dr., Hacettepe Üniversitesi, E-posta: seldaozdemir@hacettepe.edu.tr, https://orcid.org/0000-0001-9205-5946
} 


\section{Giriş}

Oyun; nesneler, olaylar, duygular ve ilişkiler hakkında çocukların yorumlamalar yapmasını sağlayarak öğrenmelerini destekleyen bir araçtır (Lifter \& Bloom, 1998; Lifter, 2000). Tüm çocuklar için gelişimin aynası olan oyun, görme yetersizliğinden etkilenmiş olan çocuklar için de gelişimsel becerilerin deneyimlendiği ve geliştiği bir süreç olarak kabul edilmektedir (Skellenger \& Hill, 1994). Görme yetersizliğinden etkilenen çocukların oyunlarıyla ilgili yapılan sınırlı sayıda araştırmada, çocukların görsel bilgi sınırlılıklarının oyun davranışlarına ve gelişimsel ilerlemelerine olumsuz yönde etkilerinin araştırmacılar tarafindan rapor edildiği dikkat çekmektedir (Recchia, 1987; Warren, 1994). Görme yetersizliği olan çocukların oyunlarında sıklıkla işitsel uyaran sağlayan oyuncakları tercih ettikleri (Fewell \& Kaminski, 1988), ağırlıklı olarak nesneleri veya oyuncakları keşfetmeye yönelik oyun davranışları sergiledikleri (Celeste, 2005), oyuncakları keşfetmek için daha çok tekrarlı oyun davranışları gösterdikleri (Recchia, 1987), özellikle sembolik oyunda gecikmeler sergiledikleri (Rogers \& Puchalski, 1984) ve daha çok yalnız oyun oynadıkları (Erwin, 1993), doğal oyun bağlamında gerçekleştirilen oyun davranışlarını değerlendirme araştırmalarında gözlenmiştir. Ek olarak pek çok araştırmacı da oyun sırasında görme yetersizliği olan çocukların yetişkinlerle kurdukları etkileşimi, akran etkileşimine tercih ettiklerini rapor etmişlerdir (Kekelis, 1992; Parsons, 1986; Preisler, 1993). Bazı araştırmacılar da görme yetersizliği olan çocukların sergiledikleri sembolik oyun gecikmelerinin çocukların yaşları ilerledikçe arttığını belirtmiştir (Parsons, 1986; Tröster \& Brambring, 1994).

Oyun becerileri çocuklarda pek çok gelişimsel beceri ile ilişkilendirilse de sembolik düşüncenin bir yansıması olarak kabul edilen sembolik oyun ve Zihin Kuramı arasındaki ilişki Zihin Kuramının ilk ortaya konulduğu tarihlerden beri araştırmacıların ilgi odağı olmaya devam etmektedir (Baron-Cohen \& Swettenham, 1997; Flavell vd., 1983; Leslie, 1987, 1992, 1994; Schwebel vd., 1999). Öte yandan söz konusu ilişkinin görme yetersizliği olan çocuklarda bugüne kadar hiç incelenmemesi de alanyazındaki dikkat çekici eksikliklerdir. Bilişsel süreçlerden biri olan ve kendisinin ve başkalarının davranışlarını fark etme, yorumlama, çıkarım yapma ve atıf yapabilme becerisi olan Zihin Kuramı (Wellman, 2002), insan gelişiminde doğumdan itibaren süregelen taklit, ortak dikkat, nesne sürekliliği, sosyal referans alma, sembolik düşünme gibi gelişimsel yapıtaşlarının deneyimlenmesi ile gelişen ve zaman içinde oluşan bir bilişsel süreçtir (Flavell, 2004). Görme yetersizliği olan çocuklarda Zihin Kuramı gelişimi uzunca bir süredir, çocukların görsel sınırlılıkları nedeniyle görsel bakış açısı almada sergiledikleri sınırlılıkların (Bigelow, 2003; Farrenkopf \& Davidson, 1992) zihinsel bakış açısı almaya da yansıyabileceği öngörüsüyle çok merak edilen bir araştırma konusu olmuştur. Bu kapsamda bazı araştırmalarda görme yetersizliği olan çocukların Zihin Kuramı görevlerinde gören akranlarına göre daha düşük puanlar aldıkları rapor edilmiş (Begeer vd., 2014; Green vd., 2004; Hobson, 1990; McAlpine \& Moore, 1995; Minter vd., 1998; Recchia, 1997; Roch-Levecq, 2006), bazı araştırmalarda ise görme yetersizliği olan çocuklarla gören çocukların birbirlerine benzer puanlar aldıkları gösterilmiştir (Anghel, 2012; Bartoli vd., 2019; Baştuğ, 2016; Işıtan \& Özdemir, 2019; Pijnacker vd., 2012). Green ve diğerleri (2004) Zihin Kuramı gelişiminde başkalarıyla kurulan görsel etkileşimin önemli olduğunu vurgulayarak iletişim sırasında mimik ve jest kullanımının sınırlı olmasıyla birlikte görme yetersizliği olan çocukların Zihin Kuramı becerilerinde gecikmeler yaşayabileceklerini belirtmişlerdir. Bu doğrultuda, özellikle doğuştan ve ağır görme yetersizliğinden etkilenmiş olan çocukların Zihin Kuramında problemler yaşadıklarını yaptıkları bir araştırmada rapor etmişlerdir (Green vd., 2004).

Alanyazındaki araştırmalar incelendiğinde, görme yetersizliği olan çocuklarla yapılan Zihin Kuramı değerlendirmelerinde literatürde yaygın olarak kullanılan görevlerde farklılıklar olduğu dikkat çekmektedir. Örneğin Yanlış Kanı Atfı görevlerinden olan Wimmer ve Perner (1983) tarafından geliştirilen Yer Değiştirme görevinde bulunan iki karakterin bir nesnenin yerinin değiştirilmesi durumuna ilişkin olarak farklılaşan zihinsel durumlarına yönelik bir değerlendirilme gerçekleştirilmektedir. Yer Değiştirme görevi alanyazında en yaygın kullanılan görevlerden birisi olmuş, farklı materyal ve çeşitlenen hikayelerle oluşturularak yıllar boyunca kullanılan bir değerlendirme görevi haline gelmiştir (Baron-Cohen, 2000). Yanlış Kanı Atfı görevlerinden bir diğeri olan Beklenmeyen İçerik görevinde ise bir özelliğe sahip nesnenin içerisine farklı özellikte materyaller yerleştirilerek bireyin başkalarının zihinsel durumlarını yordamasına ilişkin bir değerlendirme yapılmaktadır. İlk örnekleri Astington ve Jenkins (1999) tarafından çikolata kutusu testi olan bu görev alanyazında sıklıkla kullanılırken, görme yetersizliği olan çocuklarda da lolipop kağıdının içine pinpon topu koyma gibi değerlendirme örnekleri mevcuttur (Baştuğ, 2016). Alanyazında Zihin Kuramı değerlendirmelerinde yaygın olarak kullanılan bir diğer görev ise Görünüm Gerçeklik görevidir. Bu görevde ise nesnelerin göründüğünden aslında farklı olabileceğine dair durum, bireyin başkalarının zihinsel durumlarını yordaması düzeyinde değerlendirilmektedir. Flavell ve diğerleri (1992) tarafından geliştirilen bu görevde taşa benzeyen ama aslında sünger olan bir nesne ile çocukların başkalarına dair zihinsel durumları tahmin edebilme becerileri değerlendirilmektedir. Alanyazında 
görme yetersizliği olan çocuklarla gerçekleştirilen Zihin Kuramı değerlendirmelerinde yaygın olan Beklenmeyen Yer Değiştirme ve Beklenmeyen İçerik görevlerinin kullanıldığı görülmektedir. Ancak bu araştırma kapsamında yapılan incelemelerde Görünüm Gerçeklik görevleri değerlendirmelerinin de uygulandı̆̆ı Zihin Kuramı araştırmalarına ulaşılamamıştır.

Görme yetersizliği olan çocuklara yapılan Zihin Kuramı araştırmalarında birbiri ile farklılaşan bulgular yaygın olarak rapor edilse de, araştırmalardan kaynaklanan sınırlılıklar rapor edilen sonuçları yorumlamayı oldukça güç hale getirmektedir. İlk olarak, görme yetersizliği olan çocuklar ve gören çocukların farklılıklarını inceleyen pek çok araştırmada karşılaştırma grupları arasında dil-bilişsel gelişim denkliğinin sağlanmamasının standart ölçme araçları kullanılarak dil-bilişsel becerilerinin ölçümlenmesinde yaşanan sınırlılıkları ortaya çıkardığı, ayrıca bu durumun araştırmalarda rapor edilen gruplar arası farklılıkları etkileyebileceği önemli bir sınırlılık olarak değerlendirilmektedir. Diğer bir ifade ile gruplar arasında rapor edilen farklılıklar, aslında görme yetersizliği olan çocukların dil bilişsel gelişim düzeylerinin gören akranlarıyla eş düzeyde olmamasından kaynaklanabilir. İkinci olarak, görme yetersizliği olan çocuklarla yapılan pek çok araştırmada katılımcı görme yetersizliği olan çocukların görme düzeyleriyle ilgili ayrıntılı bilgiye yer verilmediği dikkat çekmektedir. Pek çok araştırmada görme yetersizliği olan çocukların kaç tanesinin doğuştan görme yetersizliğine sahip olduğu ve aynı zamanda ağır görme yetersizliği sergilediği ve kaç tanesinin de az gören çocuklar olduğu ile ilgili sınırlı düzeyde bilgi verildiği görülmektedir. Ağır görme yetersizliği olan çocukların bilişsel sınırlılıklar sergileme olasılıkları az gören çocuklara oranla daha yüksektir. Bu kapsamda daha çok ağır görme yetersizliği olan çocuklarla uygulanan araştırmalarda, katılımcı grupları arasında bilişsel gelişim farkı çıkma olasılı̆̆ı da yükselmektedir. Bu durumun temel nedenlerinden birisi ağır görme yetersizliklerinin bireylerde sıklıkla nörolojik hasarlardan kaynaklanabilmesidir. Örneğin kortikal görme bozukluğu (KGB) çocuklarda en sık görülen ağır görme yetersizlikleri nedenleri arasındadır (Brodsky vd., 2002). KGB nörolojik temelli bir görme bozukluğudur ve gözde değil, beynin görme alanında oluşan hasarlardan dolayı çocukların ağır görme yetersizliği sergilemelerine neden olmaktadır. Beynin görme bölümünde oluşan hasarlar, beynin farklı alanlarında da görülebilmektedir. Dolayısıyla KGB olan çocuklarda bilişsel ve genel gelişim problemleri sıklıkla gözlemlenebilmektedir (Brodsky vd., 2002; Fazzi vd., 2007; Huo vd., 1999). Bu bilgiler çerçevesinde ağır görme yetersizliği olan ve gören çocukların Zihin Kuramı düzeylerinin karşılaştırılmasında dil-bilişsel gelişim denkliğinin sağlanması daha da önemli hale gelmektedir.

Üçüncü olarak, görme yetersizliği olan çocuklarla Zihin Kuramı değerlendirmelerinde çocuklara sunulan görsel materyallerin araştırma sonuçlarını etkilediği bazı araştırmacılar tarafından rapor edilmektedir (Brambring \& Asbrock, 2010; Pijnacker vd., 2012). Pijnacker ve diğerleri (2012), Zihin Kuramı değerlendirmelerinde kullanılan hikayelerdeki olay, karakter, durum gibi sözlü bilgilerin işitsel olarak işlenmesinde görme yetersizliği olan çocukların daha başarılı olduklarını vurgulamışlardır. Alanyazındaki araştırmalar da bu görüşleri doğrular niteliktedir. Nitekim pek çok araştırmacı görme yetersizliğinden etkilenmiş çocukların işitsel sözel bilgiye dair bellek kapasitelerinin güçlü olduğunu rapor etmişlerdir (Hull \& Mason, 1995; Raz vd., 2007; Röder vd., 2001; Swanson \& Luxenberg, 2009). Bu bağlamda araştırmacılar, görme yetersizliğinden etkilenmiş çocuklarla önceki yıllarda yapılan Zihin Kuramı araştırmalarının farklı sonuçları rapor eden bulgularına dikkat çekmişler ve görme yetersizliği olan çocukların işitsel bilgiyi daha iyi işlemleme süreçleri nedeniyle araştırma planlamaları sırasında bu duruma uygun uyarlamalar yapılması gerektiğine vurgu yapmışlardır (Pijnacker vd., 2012; Tadic vd., 2010). Bartoli ve diğerleri (2019) ise, görme yetersizliği olan çocuklar ile gören çocukların Zihin Kuramı farklılıklarının daha kapsamlı araçlarla değerlendirilmesinin gerekliliği üzerine yaptıkları bir çalışmada, Zihin Kuramı hikayelerinin sesli versiyonunu geliştirmiş ve görme yetersizliği olan çocuklar ile gören çocukların performanslarını karşılaştırmışlardır. Sesli uyarlamalar aracılığıyla sunulan görevlerde, iki katılımcı grup arasında anlamlı bir farklılık bulunmadığı araştırmacılar tarafından rapor edilmiştir. Görme yetersizliği olan çocukların görsel bilgi sınırlılığı (Recchia, 1987; Warren, 1994) ile işitsel dikkat gerektiren görevlerde güçlü performans sergileyebilmeleri (Boaz vd., 2011) göz önüne alındığında, Zihin Kuramı görevlerinde kullanılacak görevlerin işitsel açıdan etkili sunulmasının ve hikayelerde kullanılacak olan materyallerin dokunsal özelliklerde olmasının araştırmaların iç geçerliği açısından önemli olduğu açıktır. Son olarak görme yetersizliği olan çocuklarda Zihin Kuramı becerileri farklı görev türleri uygulanarak değerlendirilmektedir. Araştırmalarda Beklenmeyen İçerik, Beklenmeyen Yer Değişikliği ve Görünüm Gerçeklik gibi yaygın kullanımı olan görevlerin kullanıldığı görülse de, mevcut araştırmalarda her bir görevin uygulama sayısı, görevlerde sorulan soru sayısı ve görev puanlamaları farklılaşabilmektedir. Bu durum, özellikle görme yetersizliğinden etkilenmiş çocuklarla yapılan araştırmalarda farklılaşan bulguları rapor eden çalışma sonuçlarının bir bütün olarak değerlendirilmesini güçleştirmektedir. 
Görme yetersizliği olan çocukların gelişimsel farklılıklarını inceleyen pek çok araştırmacı, görme yetersizliği olan çocukların ortak dikkat becerilerinde gecikmeler sergilediklerini (Bigelow, 2003; Mulford, 1983; Ross, 2017; Rowland, 1984), bakış açısı alma sınırlılıklarını (Bigelow, 2003; Farrenkopf \& Davidson, 1992), ebeveyn-çocuk etkileşimi sınırlılıklarını (İrtiş \& Özdemir, 2019), çevre ile etkileşimlerde görsel paylaşım yoksunluğunu (Green vd., 2004; Hobson, 1990; Minter vd., 1998), sosyal uyum problemlerini (Demir \& Özdemir, 2016a; Demir \& Özdemir, 2016b; Özkubat ve Özdemir, 2012, 2014) ve oyun davranışlarında akranlarına göre anlamlı farklılıklar olduğunu (Aslan vd., 2015; Fewell \& Kaminski, 1988; Gerhardt, 1982; Lewis vd., 2000; Recchia, 1997; Şahin \& Özdemir, 2015) rapor etmişlerdir. Özellikle ortak dikkat ve bakış açısı alma sınırlılıklarının öncül beceriler olarak görme yetersizliği olan çocuklarda Zihin Kuramı ve oyun becerileri gelişimini etkilediği pek çok araştırmacı tarafından vurgulanmaktadır (Anghel, 2012; Pring vd., 1998). Alanyazında görme yetersizliği olan çocukların sembolik oyun becerilerinde gecikmeler görülmesinin (Aslan vd., 2015; Recchia, 1997; Rettig, 1994; Skellenger \& Hill, 1994; Skellenger \& Rosenblum, 1997; Şahin \& Özdemir, 2015; Troster \& Brambring, 1994), gören çocuklarda oyun ve Zihin Kuramı ilişkisini inceleyen araştırmaların yaygınlığına rağmen (Baron-Cohen \& Swettenham, 1997; Flavell vd., 1983; Leslie, 1987, 1992, 1994; Schwebel vd., 1999), görme yetersizliği olan çocuklarda oyun ve Zihin Kuramı ilişkisi henüz incelenmemiştir. Üstelik görme yetersizliği olan çocuklarda Zihin Kuramı, araştırmacıların uzunca bir süredir ilgisini çeken birbiri ile çelişkili bulguların rapor edildiği bir araştırma alanı olmaya devam etmektedir (Anghel, 2012; Bartoli vd., 2019; Işıtan \& Özdemir, 2019; Özdemir, 2016).

Çocuklarda oyun becerileri ve Zihin Kuramı gelişiminde görme becerilerinin etkilerinin incelenmesi açısından görme yetersizliği olan çocuklarla yapılacak araştırmalar büyük önem taşımaktadır. Çocuklarda nesnelere atıfta bulunma becerisindeki gecikmenin, başkalarının istek ve niyetlerini anlamada gecikmeler sergilemeleriyle eş güdümlü olabileceği araştırmacılar tarafından tartışılmaktadır (Özdemir, 2016). Ancak görme becerisinin oyun ve Zihin Kuramı ile olası ilişkilerini anlayabilmek için yukarıda tartışılan araştırma problemlerinin kontrol edildiği, iyi desenlenmiş araştırmalara gereksinim duyulmaktadır. Söz konusu araştırmalarda katılımcı görme yetersizliği olan ve gören çocukların dil-bilişsel gelişim denkliğinin sağlanması kritik ölçüde önemlidir. Öte yandan görme yetersizliği olan çocuklar bir grup olarak incelenseler de az gören ve ağır görme yetersizliği olan çocukların da ayrı gruplar olarak ele alınması, görme becerisinin oyun becerileri ve Zihin Kuramı ile ilişkisi hakkında kapsamlı bilgiyi sağlaması açısından gereklidir. Bu kapsamda bu araştırmada yaşları 48 ila 72 ay arasında değişen, dil ve bilişsel gelişim yaşları eşitlenen görme yetersizliği olan ve gören çocukların gelişimsel oyun seviyelerinin karşılaştırılması ve çocukların oyun seviyeleri ile Zihin Kuramı puanları arasındaki ilişkilerin incelenmesi hedeflenmiştir. Bu amaç kapsamında aşağıda sıralanan araştırma sorularına cevap aranmıştır:

1. Okul öncesi dönemdeki görme yetersizliği olan ve gören çocukların Gelişimsel Oyun Değerlendirmesi Aracı ile belirlenen gelişimsel oyun seviyeleri arasında fark var mıdır?

2. Farklı görme düzeylerine göre okul öncesi dönemdeki çocukların Gelişimsel Oyun Değerlendirmesi Aracı ile belirlenen gelişimsel oyun seviyeleri arasında fark var mıdır?

3. Okul öncesi dönemdeki görme yetersizliği olan ve gören çocukların gelişimsel oyun seviyeleri ile Zihin Kuramı, Birinci Derece Yanlış Kanı Atfı puanları arasında ilişki var mıdır?

4. Farklı görme düzeylerine göre çocukların gelişimsel oyun seviyeleri ile Zihin Kuramı, Birinci Derece Yanlış Kanı Atfı puanları arasında ilişki var mıdır?

\section{Yöntem}

\section{Araştırma Deseni}

Bu araştırmada, okul öncesi dönemde görme yetersizliği olan ve gören çocukların gelişimsel oyun seviyelerinin Zihin Kuramı düzeyleri ile ilişkisinin incelenmesi amacıyla, nedensel karşılaştırma deseni kullanılmıştır. Nedensel karşılaştırma deseni; var olan bir olay ya da durumun nedenlerini, nedenleri etkileyen değişkenleri ve sonuçlarını belirlemeyi amaçlayan bir araştırma desenidir (Büyüköztürk vd., 2008). Nedensel karşılaştırma desenleri ile yapılan araştırmalar kapsamında neden sonuç ilişkisi incelenerek olası değişkenlerin sonuçları belirlenebilmektedir. Neden sonuç ilişkisi kurma nedeniyle deneysel çalışmalara benzese de, farklı grupların olmaması ve araştırmacının müdahale etmemesi nedenleriyle de deneysel araştırmalardan ayrılmaktadır (Büyüköztürk vd., 2008). 


\section{Çalışma Grubu}

Bu araștırmaya İstanbul ilinde ikamet eden, Millî Eğitim Bakanlığı'na bağlı okul ve kurumlarda eğitimine devam eden görme yetersizliği olan 30 çocuk ve gören 30 çocuk katılmıştır. Araştırma kapsamında katılımcı görme yetersizliği olan çocukların 19'u az gören, 11'i ise ağır görme yetersizliği olan çocuklar olarak belirlenmiştir. Az gören olma durumu; gören gözün 20/70 görme gücüne ya da 20/200 görme keskinliğine sahip olma durumu olarak tanımlanırken, ağır görme yetersizliği sergileme durumu ise gören gözün onda birine yani 20/200'lük görme keskinliğine ya da daha azına sahip olma ve bireyin sahip olduğu görme alanının 20 dereceden az olma durumu olarak tanımlanmaktadır (World Health Orginazation [WHO], 2013).

Araştırmanın çalışma grubunda yer alan görme yetersizliği olan çocuklar; a) 48-72 ay aralığında olma, b) az gören veya ağır görme yetersizliği tanısı almış olma ve c) herhangi bir ek yetersizlik ve dil ve bilişsel gelişim alanında gecikme sergilememe ölçütlerini taşırken, gören katılımcı çocuklar ise; a) 48-72 ay aralığında olma ve b) herhangi bir yetersizlik ve gelişimsel gecikme sergilememe özelliklerine sahip çocuklar olarak belirlenmişlerdir. Araştırmaya katılan çocukların gelişimsel değerlendirmeleri Ankara Gelişim Tarama Envanteri (AGTE) (Savaşır vd., 1993) uygulanarak gerçekleştirilmiştir. Araştırmada görme yetersizliği olan ve gören katılımcı çocukların bilişsel ve dil gelişimlerinin gruplar arasında anlamlı farklılık göstermemesi ve katılımcı çocukların bilişsel ve dil gelişimlerinde gecikme olmaması koşullarının aranması nedeniyle aday katılımcı çocukların AGTE uygulamaları ile değerlendirmeleri yapılmıştır. Görme yetersizliği olan aday katılımcı çocuk sayısı 55, gören aday çocuk sayısı ise 50 olarak listelenmiştir. Katılımcı çocukların yaş, cinsiyet, görme düzeyi ve eğitim düzeylerine göre dağılımları Tablo 1'de verilmiştir.

Tablo 1

Katılımcıların Yaş, Cinsiyet, Görme Düzeyi ve Eğitim Düzeylerine Göre Dağıllımları

\begin{tabular}{|c|c|c|c|c|c|}
\hline & \multirow{2}{*}{ Değişken } & \multicolumn{2}{|c|}{ Görme yetersizliği } & \multicolumn{2}{|c|}{ Gören } \\
\hline & & $N$ & $\%$ & $N$ & $\%$ \\
\hline \multirow{4}{*}{ Yaş/Ay } & $48-53$ ay & 5 & 16.7 & 9 & 30.0 \\
\hline & $54-59$ ay & 6 & 20.0 & 7 & 23.3 \\
\hline & $60-66$ ay & 10 & 33.3 & 8 & 26.7 \\
\hline & $67-72$ ay & 9 & 30.0 & 6 & 20.0 \\
\hline \multirow{2}{*}{ Cinsiyet } & $\mathrm{K}_{1 \mathrm{Z}}$ & 8 & 26.7 & 12 & 40.0 \\
\hline & Erkek & 22 & 73.3 & 18 & 60.0 \\
\hline \multirow{3}{*}{ Görme düzeyi } & Ağır görme yetersizliği & 11 & 36.7 & - & - \\
\hline & Az gören & 19 & 63.3 & - & - \\
\hline & Gören & - & - & 30 & 100.00 \\
\hline \multirow{3}{*}{ Eğitim } & Anaokulu & - & _ & 17 & 56.7 \\
\hline & Destek eğitim & 22 & 73.7 & - & - \\
\hline & Tersine kaynaştırma & 8 & 26.7 & 13 & 43.3 \\
\hline
\end{tabular}

Aday katılımcı çocukların AGTE sonuçlarına göre gelişimsel gecikmesi olmayan görme yetersizliği olan 30 çocuk ile gelişimsel gecikmesi olmayan gören 30 çocuk araştırmaya dahil edilmiştir. AGTE verilerine dair bulgular Tablo 2'de gösterilmiştir. Bu araştırma kapsamında katılımcı görme yetersizliği olan ve gören çocuklara AGTE genel gelişim alanında ve diğer alt alanlarda yapılan gruplararası karşılaştırmalardan elde edilen bulgular, görme yetersizliği olan ve gören katılımcıların Dil-Bilişsel gelişim alanında anlamlı gelişimsel farklılık göstermediklerini $(p>.05)$ göstermiştir.

Tablo 2

Katılımcıların Ankara Gelişim Tarama Envanteri'ne Göre Gelişim Puanları Dağılımları

\begin{tabular}{lccc}
\hline & Görme yetersizliği $(n: 30)$ & Gören $(n: 30)$ & $p$ \\
\hline Yaş/Ay & $60.97(r: 48-70)$ & $58.13(r: 48-71)$ & .165 \\
Kız/Erkek & $8 / 22$ & $12 / 18$ & - \\
Genel Gelişim & 139.27 & 144.43 & $.000^{\mathrm{a}}$ \\
Dil-Bilişsel & 58.80 & 59.10 & .739 \\
İnce Motor & 21.40 & 24.00 & $.000^{\mathrm{a}}$ \\
Kaba Motor & 23.63 & 24.00 & $.000^{\mathrm{a}}$ \\
Sosyal Beceri/Öz Bakım & 35.30 & 37.40 & $.000^{\mathrm{a}}$ \\
\hline
\end{tabular}




\section{Veri Toplama Araçları}

\section{Demografik Bilgi Formu}

Araştırmada katılımcıların ebeveynlerinden çocuklarının takvim yaşı, görme yetersizliği türü ve derecesi, görme yetersizliğinin ne zaman oluştuğu, ebeveynlerin eğitim durumu gibi bilgiler araştırmacılar tarafindan hazırlanan demografik bilgi formunun doldurulması ile toplanmıştır.

\section{AGTE}

AGTE, Savaşır, Sezgin ve Erol (1993) tarafından geliştirilen, anne ve babadan alınan bilgiler ile çocuğun takvim yaşına uygun olarak doldurulan bir değerlendirme aracıdır. AGTE'nin içeriğinde çocuğun 0-6 yaş arası gelişimine yönelik maddeler ve 5 gelişim alanı bulunmaktadır. Bu alanlar: Dil-Bilişsel, İnce Motor, Kaba Motor, Sosyal Beceri-Özbakım ve Genel Gelişimdir. Ölçekte, her gelişim alanı kendi içinde değerlendirilir ve ayrıca dört farklı gelişim alanının toplamı alınarak Genel Gelişim alanında da bir değerlendirme yapılır (Savaşır vd., 1994). Testin geliştirilmesi sürecinde farklı yaş gruplarında hesaplanan test tekrar test güvenirlikleri; Dil-Bilişsel gelişimde $0-12$ ay için, $.93,13-44$ ay için . $97,45-72$ ay için .88, İnce Motor gelişimde $0-12$ ay için .93, 13-44 ay için .95, 45-72 ay için ise .84, Kaba Motor gelişimde 0-12 ay için .91, 13-44 ay için .80, 45-72 ay için ise .19, Sosyal Beceri-Özbakım gelişiminde, $0-12$ ay için .92, 14-44 ay için .85, $45-72$ ay için .37 olarak hesaplanmıştır. AGTE 1-3 aylar ile 5 yaş 12 ay arası çocuklar için uygundur. Yazarlar, ölçeğin gelişim geriliği veya gecikmesi olan 72 ayı geçmiş çocuklar için de uygulanabileceğini açıklamışlardır (Savaşır vd., 1994).

\section{Gelişimsel Oyun Değerlendirme Aract}

Gelişimsel Oyun Değerlendirme Aracı (Developmental Play Assessment-DPA; Lifter, 2000), çocukların oyun gelişim seviyelerini belirlemek ve oyun temelli müdahale programı oluşturmak amacıyla, okul öncesi dönemdeki normal gelişim gösteren ve gelişimsel gecikme sergileyen çocukları hedef alan bir değerlendirme aracı ve programıdır. Gelişimsel Oyun Değerlendirme Aracı oyun gelişimini, sekiz farklı kategoride tanımlanan davranışsal örneklerle ve ölçütlerle değerlendirir (Lifter, 2000). Aracın içeriğinde gelişimsel oyun seviyelerini açıklayan 8 madde, 15 farklı aşamaya ayrılmıştır. Çocukların oyunları, 1a) Ayrımsız Oyun, 2a) Ayrımlı Oyun, 2b) Birleşimleri Parçalarına Ayırma, 3a) Görünüm Birleşimleri, 3b) Genel Birleşimler, 3c) Kendini Sembolize Etme, 4) Özel Fiziksel Birleşimler, 5a) Çocuk Aracılı, 5b) İşlev Birleşimleri, 6a) Tek Şema Sırası, 6b) Eklemeler, 7a) Bebek Aracılı, 7b) Çoklu Şema Sırası, 8a) Sosyodramatik Oyun ve 8b) Tematik Hayali Oyun olarak sıralanmıştır (Lifter, 2000). Aşağıda Tablo 3'te Gelişimsel Oyun Değerlendirmesi'nde kullanılan oyun seviyelerindeki kategoriler ve açıklamaları yer almaktadır.

\section{Tablo 3}

Gelişimsel Oyun Değerlendirmesi’nde Kullanılan Oyun Kategorilerinin Tanımlamaları ve Stralamaları

\begin{tabular}{cll}
\hline Seviye & \multicolumn{1}{c}{ Kategori } & \multicolumn{1}{c}{ Açıklama } \\
\hline I & Ayrımsız oyun & Tüm objelere benzer davranır. \\
II & Ayrımlı oyun & $\begin{array}{c}\text { Ayrı objelerle ayrı eylemler gerçekleştirir. Objeleri fiziksel ve kullanım } \\
\text { işlevlerine göre birbirinden ayırır. }\end{array}$ \\
& Birleşimleri parçalarına ayırma & Nesnelerin fiziksel özelliklerine göre parçalarını ayırır. \\
& Görünüm birleşimleri & Görünümü yeniden birleştirir. Bileşimlerin görünümüne göre obje \\
birleşimleri oluşturur.
\end{tabular}


Gelişimsel Oyun Değerlendirmesi için, hazırlanmış olan ortam ve oyuncak setleri ile çocuğun doğal oyun sırasındaki davranışları kayıt altına alınarak çocuğun gerçekleştirdiği oyun etkinliklerinin değerlendirilmesi sağlanır. Bu araç ile çocuğun performansı sadece doğal oyun davranışları kapsamında değerlendirilerek çocukların olası dil ve iletişim güçlüklerinden bağımsız olarak sadece oyun davranışlarının değerlendirilmesi sağlanır (Lifter, 2000).

\section{Zihin Kuramı-Birinci Derece Yanlı̧ Kanı Atfı Görevleri}

Katılımcı çocukların Zihin Kuramı, Birinci Derece Yanlış Kanı Atfı düzeyleri üç kategoride hazırlanan görevler ve çocukların görevlerde kendilerine sorulan sorulara verdikleri yanıtlar ile değerlendirilmiştir. Yanlış Kanı Atfı görevleri, bireyin başkasının davranışlarının farkında olma ve başkasının davranışlarını izleyerek, bireyin diğer davranışları hakkında çıkarım yapma yetisini belirleyen görevlerden oluşmaktadır (Wimmer \& Perner, 1983). Yanlış Kanı Atfı görevleri; Beklenmeyen Yer Değiştirme (Unexpected of Location), Beklenmeyen İçerik (Unexpected Contents) ve Görünüm Gerçekliktir (Appearance-Reality). Wimmer ve Perner (1983) tarafından geliştirilen Yer Değiştirme görevinde bir nesnenin yerinin değiştirilme durumunda bireylerin farklılaşan zihinsel durumlarının tahmin edilmesi, Astington ve Jenkins (1999) tarafından çikolata testi ile ilk defa uygulanan Beklenmeyen İçerik görevinde bir nesnenin içerisine farklı özellikte materyaller yerleştirilerek bireyin başkalarının zihinsel durumlarını yordaması ve son olarak da Flavell ve diğerleri (1992) tarafından geliştirilen Görünüm Gerçeklik görevinde ise nesnelerin göründüğünden farklı olabileceğine dair bireylerin farklılaşabilen zihinsel durumlarının değerlendirilmesi gerçekleştirilmektedir. Bu araştırma kapsamında tüm katılımcı çocuklarla Beklenmeyen Yer Değiştirme, Beklenmeyen İçerik ve Görünüm Gerçeklik görev kategorilerinin her birinde iki farklı uygulama, toplamda ise altı uygulama gerçekleştirilmiştir.

\section{Veri Toplama ve Uygulama}

Araştırmanın uygulamaları kapsamında Lifter (2000) tarafından önerilen iki standart oyuncak seti kullanılmıştır. Bu setlerde yer alan oyuncaklar çocukların Gelişimsel Oyun Değerlendirme (Lifter, 2000) aracının kullanılması sonucunca sekiz farklı oyun kategorisine yönelik oyun davranışlarının ölçümlenmesine olanak sağlamaktadır. Bu kapsamda 1. oyuncak setinde halkalar, iç içe geçmeli kutular, örtü, üzerinde giysileri olan bir bebek, kaşık ve tarak bulundurulurken, 2. oyuncak setinde ise plastik bir kutu içerisinde hayvanlar, insan figürü, kamyon, legolar, kapağı olan bir çaydanlık, bardak ve tabak bulundurulmuştur.

Katılımcı çocukların Zihin Kuramı değerlendirmeleri için üç farklı görev türünde toplam altı görev ve görevlere uygun materyal setleri hazırlanmıştır. Hazırlanan setler çalışma öncesinde görme yetersizliği olan çocuklarla pilot çalışmalar ile uygulanmış ve görevlerin görme yetersizliği olan çocuklara uygunluğu hakkında uzman görüşleri alınmıştır. Araştırmanın başından sonuna gerçekleştirilen tüm uygulamaların video kayıtları alınmıştır. Kayıtlar sırasında kullanılan kamera çocuğun görmeyeceği bir yere yerleştirilmiştir. Araştırma verileri alınan video kayıtları izlenerek hazırlanan formlara işlenmiştir. Üç grup halinde uygulanan Zihin Kuramı görevlerinin birer örnekleri aşağıda verilmiştir.

\section{Beklenmeyen Yer Değiştirme}

Beklenmeyen Yer Değiştirme görevlerinde silgi testi ve peçete testi olmak üzere iki görev uygulanmıştır.

Silgi Testi. $\mathrm{Bu}$ test içeriğinde silgi, bardak, kutu ve iki bebek bulunmaktadır. Görevde kullanılan materyaller çocuklara gösterildikten/el ve parmakları ile dokunmalarına izin verildikten sonra sorular sorulur. Görevde kullanılan hikaye: "Bir gün Nazlıcan silgisini almış kutusunun içine koymuş. Nazlıcan dışarıya çıkmış. Ömer gelmiş kutunun içinden silgiyi almış ve bardağın içine koymuş. Ömer de dışarıya çıkmış. Nazlıcan gelmiş." denir ve hikaye ile ilgili sorular sorulur.

Kontrol sorusu: Nazlıcan silgiyi nereye koymuştu? Doğru cevap: Kutunun içine.

Kontrol sorusu: Şimdi silgi nerede? Doğru cevap: Bardağın içinde.

Zihin Kuramı Test Sorusu: Nazlıcan silgiyi nerede arayacak? Doğru cevap: Kutunun içinde.

\section{Beklenmeyen İçerik}

Beklenmeyen İçerik görevlerinde lolipop ve sakız testi uygulamaları gerçekleştirilmiştir.

Lolipop Testi. Bu test içeriğinde lolipop poşetine sarılmış bir top bulunmaktadır. Kullanılan materyal çocuğa gösterildikten/el ve parmakları ile dokunmasına izin verildikten sonra sorular sorulur. 
Kontrol Sorusu: Bu nedir? Doğru cevap: Lolipop/şeker.

Kontrol Sorusu: Bunun içinde ne olduğunu düşünüyorsun? Doğru cevap: Lolipop/şeker.

Kontrol Sorusu: Aslında içinde ne varmış? Doğru cevap: Top.

Kontrol Sorusu: Paketi açmadan önce içinde ne olduğunu düşündün/sandın? Doğru cevap: Lolipop/şeker.

Zihin Kuramı Test Sorusu: Arkadaşın bu paketin içinde ne olduğunu görmedi. Arkadaşın gelse bu paketi böyle kapalı görse bunun içinde ne olduğunu düşünür? Doğru cevap: Lolipop/şeker.

\section{Görünüm Gerçeklik}

Görünüm Gerçeklik görevlerinde çiçek testi ve bebek testi uygulamaları gerçekleştirilmiştir.

Çiçek Testi. Bu test içeriğinde çiçek görünümlü ama aslında toka olan bir nesne bulunmaktadır. Kullanılan materyal çocuğa gösterildikten/el ve parmakları ile uzaktan dokunmasına izin verildikten sonra sorular sorulur.

Kontrol Sorusu: Bu nedir? Doğru cevap: Çiçek.

Kontrol Sorusu: Al bakalım incele, aslında nedir? Doğru cevap: Toka.

Kontrol Sorusu: İncelemeden önce ne olduğunu düşündün/sandın? Doğru cevap: Çiçek.

Zihin Kuramı Test Sorusu: Arkadaşın bunun aslında ne olduğunu görmedi. Arkadaşın gelse bunu böyle görse bunun aslında ne olduğunu düşünür? Doğru cevap: Çiçek.

Yapılan araştırma için öncelikli olarak araştırmanın gerçekleştirildiği üniversiteden alınan araştırma izinleri ve Milli Eğitim Bakanlığı araştırma uygulama izinleri alınmıştır. Üniversiteden alınan 2017 yılına ait araştırma izni doğrultusunda İl Milli Eğitim Müdürlüğünden izin ve valilik olurları alınarak çalışmaya başlanmıştır. Görme yetersizliği olan ve gören çocukların İstanbul ilinde eğitimlerine devam ettikleri okul ve kurumlar belirlenmiştir. Aile izinleri alındıktan sonra tüm aday katılımeı çocukların genel gelişimsel değerlendirmeleri AGTE uygulamaları, AGTE uygulayıcısı olan birinci araştırmacı tarafından gerçekleştirilmiş ve görme yetersizliği olan ve gören katılımcılar arasında gelişimsel yetersizliği veya gecikmesi olan katılımcılar belirlenerek söz konusu katılımcıların araştırma dışında bırakılması sağlanmıştır. Anne ve babalardan alınan cevaplar doğrultusunda uygulanan AGTE'nin uygulama rehberi ile eşgüdümlü olarak anne-babanın yanıt verme konusunda emin olmadığı sorularda çocuğun ilgili beceriyi yapıp yapmadığ1 gözlenmiştir. Bu araştırmada anne baba görüşleri AGTE uygulamalarında esas alınmakla birlikte, anne babanın emin olmadığı maddelerde mümkün olan en doğal gözlemle çocukların gözlenmesi ve sağlıklı değerlendirme sonuçlarının rapor edilmesi amaçlanmıştır. Katılımcı çocukların belirlenmesinin ardından bir pilot uygulama gerçekleştirilmiştir. Pilot uygulamayı takiben ana uygulama ile araştırma verilerinin toplanması süreci tamamlanmıştır.

Görme yetersizliği olan ve gören okul öncesi dönemde olan çocukların gelişimsel oyun seviyeleri ve Zihin Kuramı becerilerini belirlemek için hazırlanan görevlerde ve doğal oyun bağlamında çocukların rahat hissedebileceği bir ortamda gözlem verilerinin kaydı alınmıştır. Gelişimsel oyun seviyeleri ve Zihin Kuramı becerileri değerlendirmeleri aynı gün ve aynı ortamda gerçekleştirilmiştir. Uygulamaların yapıldığı ortam çocuğun dikkatini dağıtacak oyuncak ve uyaranlardan arındırılmış ve ortamda sadece çocuğa sunulacak Zihin Kuramı görevi materyalleri ve oyun değerlendirmesinde kullanılan oyuncak setlerinin bulunması sağlanmıştır. Ek olarak, araştırmada katılımcı çocukların görme yetersizliğinden etkilenme durumuna bağlı olarak kullanılan materyallerdeki renk ve zemin zıtlığına dikkat edilmiştir. Görme yetersizliği olan çocuğun görme alanı, görme düzeyi ile materyale gelen $1 s ̧ 1$ yoğunluğu ve 1şı̆̆ın yönü katılımcı her bir görme yetersizliği olan çocuğun görme düzeyine uygun olarak adapte edilmiştir.

Katılımcı çocukların gelişimsel oyun seviyelerinin değerlendirmesinde iki oyuncak seti kullanılmıştır. Oyuncak setlerinin planlanmasında Gelişimsel Oyun Değerlendirmesi Aracı uygulama yönergelerinde Lifter'in (2000) önerdiği oyuncak setlerindeki oyuncakların kullanılmasına dikkat edilmiş ve set içerikleri oyuncak işlevlerinde niteliksel bir değişikliğe gitmeden görme yetersizliği olan çocuklara yönelik olarak pilot uygulamalar ve uzman görüşlerinin ardından tekrar düzenlenmiştir. Örneğin ilk sette yer alan oyuncak ayna çıkarılmıştır. Ayrıca tren yerine büyük bir kamyon kullanılması tercih edilmiştir. Oyuncaklar katılımcı çocukların yakın çevresine U harfi şeklinde dizilmiştir. Oyuncakların dizilimi sırasında birbiriyle ilişkili olan oyuncaklar aracın uygulama kuralları gereği farklı yerlere yerleştirilmiştir. Örneğin; tabak ile bardak yan yana konulmamıştır. Araştırmacı oyun başlamadan önce oyuncakları sırayla çocuğa tanıtmıştır. Görme yetersizliğinden etkilenmiş 
çocukların oyuncakları adını söyleyerek ve dokunması desteklenerek tanımaları sağlanmıştır. İlk olarak birinci oyuncak seti ardından da ikinci oyuncak seti ile uygulamalar gerçekleştirilmiş̧ir. Oyun sırasında araştırmacı çocuğun yaptığı oyun davranışlarını sözel olarak betimlemiştir. Çocuklar aynı oyuncak ile tekrarlı oyuna devam ettiği durumlarda araştırmacı diğer oyuncakları çocuğa yaklaştırmıştır veya "Burada da hayvanlar var." şeklinde hatırlatmalar yapmıştır. Gelişimsel Oyun Değerlendirmesi Aracı değerlendirmesi her bir oyuncak setinde 10'ar dakika olmak üzere 20 dakika da tamamlanmıştır. Bu süre oyuncakların düzenlenmesi görme yetersizliği olan çocuğa tanıtımı gibi zaman dilimlerini içermemektedir.

\section{Zihin Kuramı-Birinci Derece Yanlış Kanı Atfı Görevleri}

Beklenmeyen Yer Değiştirme, Beklenmeyen İçerik ve Görünüm Gerçeklik hikayelerinin anlatılması ve anlatılan hikayelerle ilgili soruların sorulması ile gerçekleşmiştir. Görevlerin uygulamaları sırasında öncelikle hikayeler için hazırlanan nesneler çocuğun önüne yerleştirilmiş ve çocuğun görevde kullanılan nesneleri tanıması için dokunması sağlanmıştır. Nesnelerin tanıtılmasının ardından hikaye anlatılmış ve hikaye sırasında adı geçen nesneye görme yetersizliği olan katılımcıların tekrar dokunması sağlanmıştır. Hikaye anlatıldıktan sonra hikayeye dair sorular sorulmuştur. Gören çocuklarla yapılan uygulamalarda ise dokunsal materyal tanıtımı ve diğer dokunsal uygulamalara yer verilmemiştir. Tüm uygulamalar sırasında gelişimsel oyun seviyelerinin değerlendirildiği uygulamaların ardından katılımcı çocukların Zihin Kuramı düzeyleri değerlendirilmiştir. İki uygulama arasında 10 dakika ara verilmiştir. Zihin Kuramı görev uygulamaları sıra etkisini engellemek için değişen sırada uygulanacak şekilde planlanmıştır. Gelişimsel Oyun Değerlendirmesi ve Zihin Kuramı değerlendirmesi toplamda 50 dakikada tamamlanmıştır. İki değerlendirmesi arasında 10 dakikalık bir araya yer verilmiştir.

\section{Gözlem Verilerinin Kodlanması}

Araştırmada, çocukların gelişimsel oyun seviyeleri ve Zihin Kuramı verilerini kodlamak amacıyla uygulamalar sırasında alınan video kayıtları kullanılmıştır. Katılımcı çocukların gelişimsel oyun seviyeleri kodlamaların birinci aşamasında çocukların tüm oyun davranışlarının transkriptasyonu gerçekleştirilmiştir. İkinci aşamada, çocukların oyun davranışları kodlamaları iki ana kodlama kategorisinde tamamlanmıştır. Bu aşamada ilk olarak çocuğun sergilediği her oyun davranışlarının Tablo 3'te listelenen hangi oyun kategorisine girdiği belirlenmiş diğer aşamada ise ilgili oyun kategorisindeki oyun davranışları sayılmıştır. Dolayısıyla ilk kodlama çocuk tarafından sergilenen bir oyun davranışının türünün belirlenmesine yönelik yapılırken, ikinci kodlama ise o oyun türünde hangi sıklıkla oyun davranışının sergilendiğini göstermiştir. Üçüncü kodlama aşamasında ise dökümü yapılan, kategorileri ve sıklıkları belirlenen oyun davranışlarının hangi düzeyde gözlendiğine karar verilir. $\mathrm{Bu}$ son aşamada her çocuğun gelişimsel oyun seviyeleri oluşturulmuştur. Bir oyun davranışının iki tür ve dört sıklığın altında gözlenmesi durumu oluşmama durumu "Yok Olma $(Y O)$ " düzeyinde kabul edilirken, iki türde ve dört sıklıkta gözlenme durumu "Oluşma $(O)$ " düzeyinde olarak kabul edilir ve en az 4 tür ve 10 sıklıkta gözlenme durumu ise "Yeterlilik (Y)" düzeyi olarak kabul edilir.

Zihin Kuramı becerileri Birinci Derece Yanlış Kanı Atfı verilerinin kodlanması ise Beklenmeyen Yer Değiştirme, Beklenmeyen İçerik ve Görünüm Gerçeklik görevlerinde tamamlanmıştır. Katılımcı çocuklara üç görev ile ilgili toplan altı hikayenin anlatımın ardından çocukların verdikleri yanıtlar puanlanmıştır. Üç görev türünde toplam puan altı olmak üzere, her görevden alınabilecek toplam puan da iki olarak belirlenmiştir. Zihin Kuramı sorularının toplam puanları 0 ve 6 arasında değişmiştir.

\section{Gözlemciler Arası Güvenirlik}

Araştırmada gözlemciler arası güvenirlik hesaplaması için seçkisiz atama yöntemiyle verilerin $\% 25{ }^{\prime} \mathrm{i}$ ikinci bir gözlemci tarafından kodlanmıştır. Kodlama öncesinde, her iki gözlemci de araştırmanın ikinci yazarından Gelişimsel Oyun Değerlendirmesi Aracı uygulama ve kodlama eğitimi almışlardır. Araştırmanın ikinci yazarı Gelişimsel Oyun Değerlendirme Aracı eğitimlerini ABD'de University of California, Autism Research Center'da almıştır. Araştırmada birinci gözlemci, görme yetersizliği olan ve gören çocukların oyun davranışlarının tamamının video kayıtlarını izleyerek Gelişimsel Oyun Değerlendirmesi puanlarını kodlamıştır. İkinci gözlemci, görme yetersizliği olan ve gören çocukların oyun videolarının \%25 ini tekrar kodlamıştır. Oyun davranışlarının gözlemciler arası güvenirlik hesaplamalarında gözlemci ve ikinci gözlemci arası güvenirlik katılımcıların $\% 25$ 'i olan görme yetersizliği olan 8 çocuk ve gören 8 çocuk ile toplam 16 katılımcıya ait verilerin değerlendirilmesi sonucunda hesaplanmıştır. Gözlemciler arası güvenirlik "Gözlenen Uygulamacı Davranışı / Planlanan Uygulamacı Davranışı X 100” formülü uygulanarak hesaplanmıştır (Bilingsley vd., 1980; Wolery vd., 2018). İki gözlemcinin gelişimsel oyun seviyesinin belirlenmesinde gözlemciler arası güvenirlik oranı \%86.7 olarak belirlenmiştir. 
Zihin Kuramı, Birinci Derece Yanlış Kanı Atfı sorularının değerlendirildiği video kayıtlarının gözlemciler arası güvenirlik kodlamalarını doktora yapmakta olan ikinci bir gözlemci gerçekleştirmiş̧tir. Zihin Kuramı düzeyi değerlendirilmesinde gözlemci ve ikinci gözlemci kodlamaları arasındaki güvenirlik katılımcıların $\% 25$ 'i olan görme yetersizliği olan 8 çocuk ve gören 8 çocuk ile toplam 16 katılımcıya ait verilerin değerlendirilmesi sonucunda hesaplanmıştır. Birinci Derece Yanlış Kanı Atfı, Beklenmeyen Yer Değiştirme görevlerinin güvenirliği \%100 olarak, Beklenmeyen İçerik görevlerinin güvenirliği \%100 olarak ve Görünüm Gerçeklik görevlerinin güvenirliği ise $\% 100$ olarak hesaplanmıştır.

\section{Uygulama Güvenirliği}

Araştırmada her çocuğun oyun ortamlarında gelişimsel oyun seviyeleri ve Zihin Kuramı Birinci Derece Yanlış Kanı Atfı test görevlerinin uygulama güvenirliğini hesaplamak amacıyla video kayıtları bağımsız bir araştırmacı tarafından izlenmiştir. Gözlenen uygulamacı davranışları gelişimsel oyun seviyeleri ve Zihin Kuramı becerileri için ayrı ayrı değerlendirilmiştir. Gelişimsel oyun seviyeleri için video kayıtlarının \% $\% 25$ 'ini izleyerek kodlayan bağımsız bir araştırmacı ile, "Gözlenen Uygulamacı Davranışı / Planlanan Uygulamacı Davranışı X 100" formülü kullanılarak araştırmanın uygulama güvenirliği belirlenmiş̧tir (Wolery vd., 2018). Araştırmada gelişimsel oyun seviyeleri uygulama güvenirliği \%95.1 çıkmıştır. Ek olarak araştırmada Zihin Kuramı, Birinci Derece Yanlış Kanı Atfi, Beklenmeyen Yer Değiştirme uygulama güvenirliği \%96.3, Beklenmeyen İçerik uygulama güvenirliği \%96.1 ve Görünüm Gerçeklik uygulama güvenirliği ise \%93.3 olarak hesaplanmıştır.

\section{Verilerin Analizi}

Yapılan çalışmada görme yetersizliği olan ve gören çocukların gelişimsel oyun seviyesi puanları ve Zihin Kuramı Birinci Derece Yanlış Kanı Atfı puanları normallik testi dağılımları için Shapiro-Wilk testi kullanılarak betimsel istatistik bulguları değerlendirilmiştir. Yapılan normallik testi bulgularına göre Shapiro-Wilk testi sonuçlarında görme yetersizliği olan ve gören çocukların gelişimsel oyun seviyesi puanlarının normal dağılıma uygun olmadığı $(p=.000<0.05)$ belirlenmiştir. Bu nedenle görme yetersizliği olan ve gören çocukların gelişimsel oyun seviyesi puanlarının karşılaştırmaları non-parametrik testlerden Mann-Whitney U testi ile yapılmış ve ağır görme yetersizliği olan, az gören ve gören çocukların gelişimsel oyun seviyeleri puanlarının karşılaştırmaları ise non-parametrik testlerden Kruskal Wallis testi ile gerçekleştirilmiştir. Görme yetersizliği olan ve gören çocukların gelişimsel oyun seviyeleri ve Zihin Kuramı Birinci Derece Yanlış Kanı Atfı düzeyleri arasındaki ilişki Spearman Korelasyon analizi ile incelenmiştir.

\section{Bulgular}

Görme Yetersizliği Olan ve Gören Çocukların "Gelişimsel Oyun Değerlendirmesi Aracı” ile Belirlenen Gelişimsel Oyun Seviyeleri Arasında Fark Var mıdır?

Görme yetersizliği olan ve gören çocukların gelişimsel oyun seviyeleri puanları arasındaki farkı belirlemek amacıyla yapılan Mann-Whitney U testinin sonuçları Tablo 4'te verilmiştir.

\section{Tablo 4}

Görme Yetersizliği Olan ve Gören Çocukların Gelişimsel Oyun Seviyeleri Puanlarının Mann-Whitney U Testi Sonuçları

\begin{tabular}{lcccccccc}
\hline & & $N$ & $\bar{X}$ & $S O$ & $S T$ & $u$ & $z$ & $p$ \\
\hline \multirow{2}{*}{ Ayrımsiz oyun } & $\mathrm{GYO}$ & 30 & 2.70 & 29.00 & 870.00 & 405.000 & -.887 & .375 \\
& $\mathrm{G}$ & 30 & 2.80 & 32.00 & 960.00 & & & \\
Ayrımlı oyun & $\mathrm{GYO}$ & 30 & 2.76 & 30.00 & 900.00 & 435.000 & -.311 & .756 \\
& $\mathrm{G}$ & 30 & 2.80 & 31.00 & 930.00 & & & \\
Birleşimleri parçalarına ayırma & $\mathrm{GYO}$ & 30 & 2.66 & 29.00 & 870.00 & 405.000 & -.852 & .394 \\
& $\mathrm{G}$ & 30 & 2.76 & 32.00 & 960.00 & & & \\
Görünüm birleşimleri & $\mathrm{GYO}$ & 30 & 2.46 & 28.50 & 855.00 & 390.000 & -1.026 & .305 \\
& $\mathrm{G}$ & 30 & 2.60 & 32.50 & 975.00 & & & \\
Genel birleşimler & $\mathrm{GYO}$ & 30 & 2.46 & 27.83 & 835.00 & 370.000 & -1.377 & .168 \\
& $\mathrm{G}$ & 30 & 2.66 & 33.17 & 995.00 & & & \\
Kendini sembolize etme & $\mathrm{GYO}$ & 30 & 1.66 & 28.13 & 844.00 & 379.000 & -1.157 & .247 \\
& $\mathrm{G}$ & 30 & 1.86 & 32.87 & 986.00 & & & \\
Fiziksel birleşimler & $\mathrm{GYO}$ & 30 & 2.33 & 27.00 & 810.00 & 345.000 & -1.801 & .072 \\
\hline
\end{tabular}


Tablo 4 (devami)

\begin{tabular}{|c|c|c|c|c|c|c|c|c|}
\hline & & $N$ & $\bar{X}$ & SO & $S T$ & $u$ & $z$ & $p$ \\
\hline Çocuk aracılı & $\begin{array}{c}\text { GYO } \\
\text { G }\end{array}$ & $\begin{array}{l}30 \\
30\end{array}$ & $\begin{array}{l}2.10 \\
2.36\end{array}$ & $\begin{array}{l}27.55 \\
33.45\end{array}$ & $\begin{array}{c}826.50 \\
1003.50\end{array}$ & 361.500 & -1.459 & .145 \\
\hline Özel birleşimler & $\begin{array}{c}\text { GYO } \\
\text { G }\end{array}$ & $\begin{array}{l}30 \\
30\end{array}$ & $\begin{array}{l}2.23 \\
2.26\end{array}$ & $\begin{array}{l}29.77 \\
31.23\end{array}$ & $\begin{array}{l}893.00 \\
937.00\end{array}$ & 428.000 & -.401 & 689 \\
\hline Tek şema sırası & $\begin{array}{c}\text { GYO } \\
\text { G }\end{array}$ & $\begin{array}{l}30 \\
30\end{array}$ & $\begin{array}{l}1.36 \\
1.66\end{array}$ & $\begin{array}{l}26.95 \\
34.05\end{array}$ & $\begin{array}{c}808.50 \\
1021.50\end{array}$ & 343.500 & -1.787 & .074 \\
\hline Eklemeler & $\begin{array}{c}\text { GYO } \\
\text { G }\end{array}$ & $\begin{array}{l}30 \\
30\end{array}$ & $\begin{array}{l}1.80 \\
2.00\end{array}$ & $\begin{array}{l}28.40 \\
32.60\end{array}$ & $\begin{array}{l}852.00 \\
978.00\end{array}$ & 387.000 & -.994 & .320 \\
\hline Bebek aracılı & $\begin{array}{c}\text { GYO } \\
\text { G }\end{array}$ & $\begin{array}{l}30 \\
30\end{array}$ & $\begin{array}{l}1.53 \\
1.86\end{array}$ & $\begin{array}{l}26.57 \\
34.43\end{array}$ & $\begin{array}{c}797.00 \\
1033.00\end{array}$ & 332.000 & -1.899 & .058 \\
\hline Çoklu şema sırası & $\begin{array}{c}\text { GYO } \\
\text { G }\end{array}$ & $\begin{array}{l}30 \\
30\end{array}$ & $\begin{array}{l}1.36 \\
2.33\end{array}$ & $\begin{array}{l}21.72 \\
39.28\end{array}$ & $\begin{array}{c}651.50 \\
1178.50\end{array}$ & 186.000 & -4.209 & .000 \\
\hline Sosyodramatik oyun & $\begin{array}{c}\text { GYO } \\
\text { G }\end{array}$ & $\begin{array}{l}30 \\
30\end{array}$ & $\begin{array}{l}1.40 \\
2.43\end{array}$ & $\begin{array}{l}21.35 \\
39.65\end{array}$ & $\begin{array}{c}640.50 \\
1189.50\end{array}$ & 175.500 & -4.392 & .000 \\
\hline Tematik hayali oyun & $\begin{array}{c}\text { GYO } \\
\text { G }\end{array}$ & $\begin{array}{l}30 \\
30 \\
\end{array}$ & $\begin{array}{l}1.23 \\
2.00 \\
\end{array}$ & $\begin{array}{l}21.68 \\
39.32 \\
\end{array}$ & $\begin{array}{c}650.50 \\
1179.50 \\
\end{array}$ & 185.500 & -4.326 & .000 \\
\hline
\end{tabular}

Not: $\mathrm{GYO}=$ görme yetersizliği, $\mathrm{G}=$ gören.

Görme yetersizliği olan ve gören çocukların gelişimsel oyun seviyeleri değerlendirildiğinde, Gelişimsel Oyun Değerlendirmesi'nde bulunan sekiz seviyenin beş seviyesinde iki grup arasında anlamlı farklılık saptanmamış, kalan üç seviyede ise anlamlı farklılıklar olduğu saptanmıştır. Farklılıklar çoklu şema sırası, sosyodramatik oyun ve tematik hayali oyun seviyelerinde gözlenmiş̧ir. Oyunun gelişimsel düzeyi karmaşıklaştıkça katılımcı çocuklar arasında farklılıklar görüldüğü belirlenmiştir.

Çoklu şema sırası oyun seviyesinde gören 30 çocuğun çoklu şema sırası sıra ortalamaları 39.28 olarak görme yetersizliği olan 30 çocuğun çoklu şema sırası sıra ortalamaları 21.72 göre yüksek çıkmıştır. Yapılan MannWhitney U testi sonuçları gören çocukların ve görme yetersizliği olan çocukların aldıkları puanların çoklu şema sırasında anlamlı farklılık gösterdiğini $(z=-4.21, p<.05)$, bu farklılığın da büyük etki düzeyinde olduğunu $(r=$ .54) göstermiş̧tir. Görme yetersizliği olan 30 çocuğun sosyodramatik oyun seviye sıra ortalamaları 21.35 , gören 30 çocuğun sosyodramatik oyun sıra ortalamaları ise 39.65 olarak bulunmuştur. Yapılan Mann-Whitney U testi sonuçları gören çocukların ve görme yetersizliği olan çocukların aldıkları puanların sosyodramatik oyun sırasında anlamlı farklılık gösterdiğini $(z=-4.39, p<.05)$, bu farklılığında da büyük etki düzeyinde olduğunu $(r=.56)$ göstermiştir. Tematik hayali oyun seviyesinde gören 30 çocuğun tematik hayali oyun sıra ortalamaları 39.32 olarak görme yetersizliği olan 30 çocuğun tematik hayali oyun sıra ortalamaları olan 21.68 'e göre yüksek çıkmıştır. Yapılan Mann-Whitney U testi sonuçları gören çocukların ve görme yetersizliği olan çocukların aldıkları puanların tematik hayali oyun seviyesinde anlamlı farklılık gösterdiğini $(z=-4.32, p<.05)$, bu farklılığında da büyük etki düzeyinde olduğunu $(r=.55)$ göstermiştir.

\section{Farklı Görme Düzeylerine Göre Katılımcıların Gelişimsel Oyun Seviyelerinin Karşılaştırılması} almaktadır.

Farklı görme düzeylerine göre çocukların gelişimsel oyun seviyesi bulgu sonuçları Tablo 5'te yer

\section{Tablo 5}

Farklı Görme Düzeylerine Göre Gelişimsel Oyun Seviyesi Kruskal Wallis Testi Sonuçları

\begin{tabular}{|c|c|c|c|c|c|}
\hline & & $N$ & $\bar{X}$ & SO & $p$ \\
\hline \multirow{3}{*}{ Ayrımsız oyun } & AGYO & 11 & 2.45 & 30.26 & \multirow{3}{*}{.143} \\
\hline & $\mathrm{AG}$ & 19 & 2.80 & 31.64 & \\
\hline & $\mathrm{G}$ & 30 & 2.84 & 32.00 & \\
\hline \multirow{3}{*}{ Ayrımlı oyun } & AGYO & 11 & 2.54 & 23.84 & \multirow{3}{*}{.081} \\
\hline & AG & 19 & 2.80 & 24.36 & \\
\hline & G & 30 & 2.89 & 31.00 & \\
\hline \multirow{3}{*}{$\begin{array}{l}\text { Birleşimleri } \\
\text { parçalarına ayırma }\end{array}$} & AGYO & 11 & 2.27 & 31.84 & \multirow{3}{*}{.142} \\
\hline & $\mathrm{AG}$ & 19 & 2.76 & 31.88 & \\
\hline & $\mathrm{G}$ & 30 & 2.89 & 32.00 & \\
\hline
\end{tabular}


Tablo 5 (devami)

\begin{tabular}{|c|c|c|c|c|c|}
\hline & & $N$ & $\bar{X}$ & SO & $p$ \\
\hline $\begin{array}{l}\text { Görünüm } \\
\text { birleşimleri }\end{array}$ & $\begin{array}{c}\text { AGYO } \\
\text { AG } \\
\text { G }\end{array}$ & $\begin{array}{l}11 \\
19 \\
30\end{array}$ & $\begin{array}{l}2.27 \\
2.57 \\
2.60\end{array}$ & $\begin{array}{l}31.87 \\
32.68 \\
32.50\end{array}$ & .162 \\
\hline Genel birleşimler & $\begin{array}{c}\text { AGYO } \\
\text { AG } \\
\text { G }\end{array}$ & $\begin{array}{l}11 \\
19 \\
30\end{array}$ & $\begin{array}{l}2.27 \\
2.57 \\
2.66\end{array}$ & $\begin{array}{l}31.47 \\
31.55 \\
33.17\end{array}$ & .084 \\
\hline $\begin{array}{l}\text { Kendini } \\
\text { sembolize etme }\end{array}$ & $\begin{array}{c}\text { AGYO } \\
\text { AG } \\
\text { G }\end{array}$ & $\begin{array}{l}11 \\
19 \\
30\end{array}$ & $\begin{array}{l}1.63 \\
1.68 \\
1.86\end{array}$ & $\begin{array}{l}28.18 \\
28.25 \\
32.87\end{array}$ & .512 \\
\hline $\begin{array}{l}\text { Fiziksel } \\
\text { birleşimler }\end{array}$ & $\begin{array}{c}\text { AGYO } \\
\text { AG } \\
\text { G }\end{array}$ & $\begin{array}{l}11 \\
19 \\
30\end{array}$ & $\begin{array}{l}2.20 \\
2.52 \\
2.56\end{array}$ & $\begin{array}{l}32.79 \\
33.00 \\
34.00\end{array}$ & .132 \\
\hline Çocuk aracılı & $\begin{array}{c}\text { AGYO } \\
\text { AG } \\
\text { G }\end{array}$ & $\begin{array}{l}11 \\
19 \\
30\end{array}$ & $\begin{array}{l}2.09 \\
2.10 \\
2.36\end{array}$ & $\begin{array}{l}27.16 \\
27.18 \\
33.45\end{array}$ & .343 \\
\hline Özel birleşimler & $\begin{array}{c}\text { AGYO } \\
\text { AG } \\
\text { G }\end{array}$ & $\begin{array}{l}11 \\
19 \\
30\end{array}$ & $\begin{array}{l}2.09 \\
2.26 \\
2.31\end{array}$ & $\begin{array}{l}23.16 \\
25.64 \\
31.23\end{array}$ & .441 \\
\hline Tek şema sırası & $\begin{array}{c}\text { AGYO } \\
\text { AG } \\
\text { G }\end{array}$ & $\begin{array}{l}11 \\
19 \\
30\end{array}$ & $\begin{array}{l}1.27 \\
1.42 \\
1.66\end{array}$ & $\begin{array}{l}25.50 \\
2857 \\
34.05\end{array}$ & .156 \\
\hline Eklemeler & $\begin{array}{c}\text { AGYO } \\
\text { AG } \\
\text { G }\end{array}$ & $\begin{array}{l}11 \\
19 \\
30\end{array}$ & $\begin{array}{l}1.73 \\
1.90 \\
2.00\end{array}$ & $\begin{array}{l}27.26 \\
30.36 \\
32.60\end{array}$ & .538 \\
\hline Bebek aracılı & $\begin{array}{c}\text { AGYO } \\
\text { AG } \\
\text { G }\end{array}$ & $\begin{array}{l}11 \\
19 \\
30\end{array}$ & $\begin{array}{l}1.45 \\
1.57 \\
1.86\end{array}$ & $\begin{array}{l}25.32 \\
27.29 \\
34.43\end{array}$ & .156 \\
\hline Çoklu şema sıras 1 & $\begin{array}{c}\text { AGYO } \\
\text { AG } \\
\text { G }\end{array}$ & $\begin{array}{l}11 \\
19 \\
30\end{array}$ & $\begin{array}{l}1.34 \\
1.36 \\
2.33\end{array}$ & $\begin{array}{l}21.55 \\
21.82 \\
39.28\end{array}$ & .000 \\
\hline $\begin{array}{l}\text { Sosyodramatik } \\
\text { oyun }\end{array}$ & $\begin{array}{c}\text { AGYO } \\
\text { AG } \\
\text { G }\end{array}$ & $\begin{array}{l}11 \\
19 \\
30\end{array}$ & $\begin{array}{l}1.36 \\
1.42 \\
2.43\end{array}$ & $\begin{array}{l}20.68 \\
21.74 \\
39.65\end{array}$ & 000 \\
\hline $\begin{array}{l}\text { Tematik hayali } \\
\text { oyun }\end{array}$ & $\begin{array}{c}\text { AGYO } \\
\text { AG } \\
\text { G }\end{array}$ & $\begin{array}{l}11 \\
19 \\
30\end{array}$ & $\begin{array}{l}1.18 \\
1.26 \\
2.00\end{array}$ & $\begin{array}{l}20.32 \\
22.47 \\
39.32\end{array}$ & .000 \\
\hline
\end{tabular}

Not: AGYO = ağır görme yetersizliği, $\mathrm{AG}=$ az gören, $\mathrm{G}=$ gören.

Yapılan Kruskal Wallis Testi sonuçlarına göre ağır görme yetersizliği olan, az gören ve gören çocukların gelişimsel oyun sevileri, çoklu şema sırası seviyesi puanları arasında istatistiksel açıdan anlamlı bir farklılık ( $p=$ $.000<.05)$ olduğu görülmektedir. Çoklu şema sırası oyun seviyesinde gören 30 çocuğun çoklu şema sirası sira ortalamaları 39.28, ağır görme yetersizliği olan 11 çocuğun çoklu şema sırası sıra ortalamaları 21.55 ve az gören 19 çocuğun çoklu şema sırası sıra ortalamaları 21.82 olarak bulunmuştur. Yapılan Kruskal Wallis testi sonuçları gören çocukların ağır görme yetersizliği olan ve az gören çocukların aldıkları puanların çoklu şema sırasında anlamlı farklılık gösterdiğini bu farklılı̆̆ında da orta etki düzeyinde olduğunu $(r=.30)$ göstermiştir.

Ağır görme yetersizliği olan 11 çocuğun sosyodramatik oyun seviye sira ortalamaları 20.68, az gören 19 çocuğun sosyodramatik oyun sıra ortalamaları ise 21.74 olarak bulunmuştur. Yapılan Kruskal Wallis testi sonuçları gören çocukların, ağır görme yetersizliği olan ve az gören çocukların aldıkları puanların sosyodramatik oyun sırasında anlamlı farklılıklar gösterdiğini bu farklılığında da orta etki düzeyinde olduğunu $(r=.33)$ göstermiştir. Tematik hayali oyun seviyesinde gören 30 çocuğun tematik hayali oyun sıra ortalamaları 39.32 ağır görme yetersizliği olan 11 çocuğun tematik hayali oyun sıra ortalamaları 20.32 ve az gören 19 çocuğun tematik hayali oyun sıra ortalama puanları 22.47 olarak bulunmuştur. Yapılan Kruskal Wallis testi sonuçları gören çocukların ağır görme yetersizliği olan ve az gören çocukların aldıkları puanların tematik hayali oyun seviyesinde anlamlı farklılık gösterdiğini bu farklılı̆̆ında da orta etki düzeyinde olduğunu $(r=.31)$ göstermiştir. 
Üç grubun gelişimsel oyun seviyeleri olan çoklu şema sırası, sosyodramatik oyun ve tematik hayali oyun seviye puanlarına göre ağır görme yetersizliği olan çocuklar ile gören çocuklar arasında istatistiksel açıdan anlamlı fark $(p=.000<.05)$ bulunmuştur. Yine yapılan post-hoc analizine göre az gören çocuklar ile gören çocukların gelişimsel oyun seviyeleri olan çoklu şema sırası, sosyodramatik oyun ve tematik hayali oyun seviye puanları arasında istatistiksel açıdan anlamlı fark $(p=.001<.05)$ bulunmuştur. Yapılan değerlendirmeler bazında üç grup arasında ağır görme yetersizliği olan çocuklar ile gören çocuklar arasında anlamlı farklılıklar olduğu ayrıca az gören çocuklar ile gören çocuklar arasında anlamlı farklılıklar olduğu dikkat çekmektedir. Ancak ağır görme yetersizliği olan çocuklar ile az gören çocuklar arasında anlamlı fark çıkmamış olup, az gören çocukların puanlarının ağır görme yetersizliği olan çocukların puanlarına göre daha yüksek olduğu gözlenmiş̧tir.

\section{Görme Yetersizliği Olan ve Gören Çocukların Gelişimsel Oyun Seviyeleri ile Zihin Kuramı Puanları} Arasında İlişki Var mıdır?

Araştırmada görme yetersizliği olan çocuklar ve gören çocukların gelişimsel oyun seviyeleri puanları ile Zihin Kuramı Birinci Derece Yanlış Kanı Atfı puanları arasında anlamlı ilişkinin olup olmadığına dair Spearman Korelasyon testi sonuçları Tablo 6'da verilmiştir.

Tablo 6

Görme Yetersizliği Olan ve Gören Çocukların Gelişimsel Oyun Seviyesi Puanları ile Birinci Derece Yanlış Kanı Atfi Puanlarinin Spearman Korelasyon Analizi

\begin{tabular}{|c|c|c|c|c|c|c|c|c|c|c|c|c|c|}
\hline & & \multicolumn{3}{|c|}{$\begin{array}{c}\text { Beklenmeyen Yer } \\
\text { Değiştirme }\end{array}$} & \multicolumn{3}{|c|}{ Beklenmeyen İçerik } & \multicolumn{3}{|c|}{$\begin{array}{l}\text { Görünüm } \\
\text { Gerçeklik }\end{array}$} & \multicolumn{3}{|c|}{ Yanlış Kanı Atfı } \\
\hline & & $N$ & $r$ & $p$ & $N$ & $r$ & $p$ & $N$ & $r$ & $p$ & $N$ & $r$ & $p$ \\
\hline Ayrımsız oyun & $\begin{array}{c}\text { GYO } \\
\text { G }\end{array}$ & $\begin{array}{l}30 \\
30\end{array}$ & $\begin{array}{l}-.23 \\
-.06\end{array}$ & $\begin{array}{l}.205 \\
.747\end{array}$ & $\begin{array}{l}30 \\
30\end{array}$ & $\begin{array}{l}-.22 \\
-.11\end{array}$ & $\begin{array}{l}.23 \\
.953\end{array}$ & $\begin{array}{l}30 \\
30\end{array}$ & $\begin{array}{l}-.13 \\
.14\end{array}$ & $\begin{array}{l}.493 \\
.447\end{array}$ & $\begin{array}{l}30 \\
30\end{array}$ & $\begin{array}{c}-.28 \\
.05\end{array}$ & $\begin{array}{l}.131 \\
.756\end{array}$ \\
\hline Ayrımlı oyun & $\begin{array}{l}\text { GYO } \\
\text { G }\end{array}$ & $\begin{array}{l}30 \\
30\end{array}$ & $\begin{array}{l}-.32 \\
-.04\end{array}$ & $\begin{array}{l}.083 \\
.809\end{array}$ & $\begin{array}{l}30 \\
30\end{array}$ & $\begin{array}{l}-.35 \\
-.18\end{array}$ & $\begin{array}{l}.053 \\
.341\end{array}$ & $\begin{array}{l}30 \\
30\end{array}$ & $\begin{array}{l}-.03 \\
.14\end{array}$ & $\begin{array}{l}.853 \\
.447\end{array}$ & $\begin{array}{l}30 \\
30\end{array}$ & $\begin{array}{r}-.35 \\
.01\end{array}$ & $\begin{array}{l}.053 \\
.959\end{array}$ \\
\hline $\begin{array}{l}\text { Birleşimleri parçalarına } \\
\text { ayırma }\end{array}$ & $\begin{array}{l}\text { GYO } \\
\text { G }\end{array}$ & $\begin{array}{l}30 \\
30\end{array}$ & $\begin{array}{l}.02 \\
.01\end{array}$ & $\begin{array}{l}.891 \\
.939\end{array}$ & $\begin{array}{l}30 \\
30\end{array}$ & $\begin{array}{r}-.19 \\
.01\end{array}$ & $\begin{array}{l}.294 \\
.933\end{array}$ & $\begin{array}{l}30 \\
30\end{array}$ & $\begin{array}{l}-.28 \\
-.25\end{array}$ & $\begin{array}{l}.127 \\
.132\end{array}$ & $\begin{array}{l}30 \\
30\end{array}$ & $\begin{array}{r}-.23 \\
.02\end{array}$ & $\begin{array}{l}.216 \\
.903\end{array}$ \\
\hline Görünüm birleşimleri & $\begin{array}{l}\mathrm{GYO} \\
\mathrm{G}\end{array}$ & $\begin{array}{l}30 \\
30\end{array}$ & $\begin{array}{l}.18 \\
.05\end{array}$ & $\begin{array}{l}.326 \\
.795\end{array}$ & $\begin{array}{l}30 \\
30\end{array}$ & $\begin{array}{l}.23 \\
.17\end{array}$ & $\begin{array}{l}.214 \\
.349\end{array}$ & $\begin{array}{l}30 \\
30\end{array}$ & $\begin{array}{l}.06 \\
-.04\end{array}$ & $\begin{array}{l}.754 \\
.807\end{array}$ & $\begin{array}{l}30 \\
30\end{array}$ & $\begin{array}{l}.23 \\
.05\end{array}$ & $\begin{array}{l}.203 \\
.770\end{array}$ \\
\hline Genel birleşimler & $\begin{array}{c}\text { GYO } \\
\text { G }\end{array}$ & $\begin{array}{l}30 \\
30\end{array}$ & $\begin{array}{c}-.08 \\
.07\end{array}$ & $\begin{array}{l}.640 \\
.681\end{array}$ & $\begin{array}{l}30 \\
30\end{array}$ & $\begin{array}{c}.23 \\
-.09\end{array}$ & $\begin{array}{l}.221 \\
.633\end{array}$ & $\begin{array}{l}30 \\
30\end{array}$ & $\begin{array}{c}.29 \\
-.14\end{array}$ & $\begin{array}{l}.108 \\
.438\end{array}$ & $\begin{array}{l}30 \\
30\end{array}$ & $\begin{array}{l}.21 \\
.06\end{array}$ & $\begin{array}{l}.261 \\
.725\end{array}$ \\
\hline Kendini sembolize etme & $\begin{array}{c}\text { GYO } \\
\text { G }\end{array}$ & $\begin{array}{l}30 \\
30\end{array}$ & $\begin{array}{l}.19 \\
.18\end{array}$ & $\begin{array}{l}.304 \\
.320\end{array}$ & $\begin{array}{l}30 \\
30\end{array}$ & $\begin{array}{l}.19 \\
.09\end{array}$ & $\begin{array}{l}.296 \\
.922\end{array}$ & $\begin{array}{l}30 \\
30\end{array}$ & $\begin{array}{l}.02 \\
.33\end{array}$ & $\begin{array}{l}.905 \\
.074\end{array}$ & $\begin{array}{l}30 \\
30\end{array}$ & $\begin{array}{l}.21 \\
.20\end{array}$ & $\begin{array}{l}.252 \\
.275\end{array}$ \\
\hline Fiziksel birleşimler & $\begin{array}{c}\text { GYO } \\
\text { G }\end{array}$ & $\begin{array}{l}30 \\
30\end{array}$ & $\begin{array}{l}-.12 \\
.06\end{array}$ & $\begin{array}{l}.505 \\
.745\end{array}$ & $\begin{array}{l}30 \\
30\end{array}$ & $\begin{array}{l}.13 \\
.39\end{array}$ & $\begin{array}{l}.492 \\
.033\end{array}$ & $\begin{array}{l}30 \\
30\end{array}$ & $\begin{array}{c}.22 \\
-.16\end{array}$ & $\begin{array}{l}.240 \\
.389\end{array}$ & $\begin{array}{l}30 \\
30\end{array}$ & $\begin{array}{r}.10 \\
-.19\end{array}$ & $\begin{array}{l}.570 \\
.292\end{array}$ \\
\hline Çocuk aracılı & $\begin{array}{c}\text { GYO } \\
\text { G }\end{array}$ & $\begin{array}{l}30 \\
30\end{array}$ & $\begin{array}{l}.43 \\
.07\end{array}$ & $\begin{array}{l}.015^{\mathrm{a}} \\
.691\end{array}$ & $\begin{array}{l}30 \\
30\end{array}$ & $\begin{array}{l}.28 \\
.11\end{array}$ & $\begin{array}{l}.113 \\
.561\end{array}$ & $\begin{array}{l}30 \\
30\end{array}$ & $\begin{array}{l}.41 \\
.03\end{array}$ & $\begin{array}{l}.023^{\mathrm{a}} \\
.837\end{array}$ & $\begin{array}{l}30 \\
30\end{array}$ & $\begin{array}{l}.56 \\
.13\end{array}$ & $\begin{array}{l}.001 \\
.473\end{array}$ \\
\hline Özel birleşimler & $\begin{array}{c}\text { GYO } \\
\text { G }\end{array}$ & $\begin{array}{l}30 \\
30\end{array}$ & $\begin{array}{c}.39 \\
-.03\end{array}$ & $\begin{array}{l}.049^{\mathrm{a}} \\
.836\end{array}$ & $\begin{array}{l}30 \\
30\end{array}$ & $\begin{array}{c}.18 \\
-.06\end{array}$ & $\begin{array}{l}.326 \\
.752\end{array}$ & $\begin{array}{l}30 \\
30\end{array}$ & $\begin{array}{c}.41 \\
-.04\end{array}$ & $\begin{array}{l}.020^{\mathrm{a}} \\
.833\end{array}$ & $\begin{array}{l}30 \\
30\end{array}$ & $\begin{array}{c}.34 \\
-.03\end{array}$ & $\begin{array}{l}.038 \\
.866\end{array}$ \\
\hline Tek şema sırası & $\begin{array}{c}\text { GYO } \\
\text { G }\end{array}$ & $\begin{array}{l}30 \\
30\end{array}$ & $\begin{array}{l}.44 \\
.07\end{array}$ & $\begin{array}{l}.014^{\mathrm{a}} \\
.677\end{array}$ & $\begin{array}{l}30 \\
30\end{array}$ & $\begin{array}{l}.12 \\
.08\end{array}$ & $\begin{array}{l}.501 \\
.644\end{array}$ & $\begin{array}{l}30 \\
30\end{array}$ & $\begin{array}{l}.37 \\
.32\end{array}$ & $\begin{array}{l}.043^{\mathrm{a}} \\
.078\end{array}$ & $\begin{array}{l}30 \\
30\end{array}$ & $\begin{array}{l}.42 \\
.16\end{array}$ & $\begin{array}{l}.020 \\
.395\end{array}$ \\
\hline Eklemeler & $\begin{array}{c}\text { GYO } \\
\text { G }\end{array}$ & $\begin{array}{l}30 \\
30\end{array}$ & $\begin{array}{l}.34 \\
.33\end{array}$ & $\begin{array}{l}.044^{\mathrm{a}} \\
.045^{\mathrm{a}}\end{array}$ & $\begin{array}{l}30 \\
30\end{array}$ & $\begin{array}{c}.31 \\
-.08\end{array}$ & $\begin{array}{l}.088 \\
.642\end{array}$ & $\begin{array}{l}30 \\
30\end{array}$ & $\begin{array}{l}.48 \\
.30\end{array}$ & $\begin{array}{l}.007^{\mathrm{a}} \\
.045^{\mathrm{a}}\end{array}$ & $\begin{array}{l}30 \\
30\end{array}$ & $\begin{array}{l}.55 \\
.40\end{array}$ & $\begin{array}{l}.001 \\
.020\end{array}$ \\
\hline Bebek aracılı & $\begin{array}{c}\text { GYO } \\
\text { G }\end{array}$ & $\begin{array}{l}30 \\
30\end{array}$ & $\begin{array}{l}.42 \\
.38\end{array}$ & $\begin{array}{l}.018^{\mathrm{a}} \\
.035^{\mathrm{a}}\end{array}$ & $\begin{array}{l}30 \\
30\end{array}$ & $\begin{array}{l}.34 \\
.18\end{array}$ & $\begin{array}{l}.063 \\
.316\end{array}$ & $\begin{array}{l}30 \\
30\end{array}$ & $\begin{array}{l}.47 \\
.32\end{array}$ & $\begin{array}{l}.007^{\mathrm{a}} \\
.048^{\mathrm{a}}\end{array}$ & $\begin{array}{l}30 \\
30\end{array}$ & $\begin{array}{l}.59 \\
.44\end{array}$ & $\begin{array}{l}.001 \\
.014\end{array}$ \\
\hline Çoklu şema sırası & $\begin{array}{c}\text { GYO } \\
\text { G }\end{array}$ & $\begin{array}{l}30 \\
30\end{array}$ & $\begin{array}{l}.52 \\
.38^{*}\end{array}$ & $\begin{array}{l}.003^{\mathrm{a}} \\
.036^{\mathrm{a}}\end{array}$ & $\begin{array}{l}30 \\
30\end{array}$ & $\begin{array}{l}.28 \\
.27\end{array}$ & $\begin{array}{l}.133 \\
.141\end{array}$ & $\begin{array}{l}30 \\
30\end{array}$ & $\begin{array}{l}.48 \\
.37\end{array}$ & $\begin{array}{l}.006^{\mathrm{a}} \\
.042^{\mathrm{a}}\end{array}$ & $\begin{array}{l}30 \\
30\end{array}$ & $\begin{array}{l}.61 \\
.49\end{array}$ & $\begin{array}{l}.000 \\
.005\end{array}$ \\
\hline Sosyodramatik oyun & $\begin{array}{c}\text { GYO } \\
\text { G }\end{array}$ & $\begin{array}{l}30 \\
30\end{array}$ & $\begin{array}{l}.58 \\
.32\end{array}$ & $\begin{array}{l}.001^{\mathrm{a}} \\
.042^{\mathrm{a}}\end{array}$ & $\begin{array}{l}30 \\
30\end{array}$ & $\begin{array}{l}.29 \\
.28\end{array}$ & $\begin{array}{l}.120 \\
.133\end{array}$ & $\begin{array}{l}30 \\
30\end{array}$ & $\begin{array}{l}.49 \\
.35\end{array}$ & $\begin{array}{l}.006^{\mathrm{a}} \\
.016^{\mathrm{a}}\end{array}$ & $\begin{array}{l}30 \\
30\end{array}$ & $\begin{array}{l}.64 \\
.60\end{array}$ & $\begin{array}{l}.000 \\
.005\end{array}$ \\
\hline Tematik hayali oyun & $\begin{array}{c}\text { GYO } \\
\text { G }\end{array}$ & $\begin{array}{l}30 \\
30\end{array}$ & $\begin{array}{l}.60 \\
.32\end{array}$ & $\begin{array}{l}.000^{\mathrm{a}} \\
.047^{\mathrm{a}}\end{array}$ & $\begin{array}{l}30 \\
30\end{array}$ & $\begin{array}{l}.18 \\
.29\end{array}$ & $\begin{array}{l}.326 \\
.109\end{array}$ & $\begin{array}{l}30 \\
30\end{array}$ & $\begin{array}{l}.38 \\
.31\end{array}$ & $\begin{array}{l}.034^{\mathrm{a}} \\
.049^{\mathrm{a}}\end{array}$ & $\begin{array}{l}30 \\
30 \\
\end{array}$ & $\begin{array}{l}.55 \\
.53\end{array}$ & $\begin{array}{l}.000 \\
.000 \\
\end{array}$ \\
\hline
\end{tabular}

Görme yetersizliği olan çocukların gelişimsel oyun seviyeleri olan çocuk aracılı, özel birleşimler, tek şema sırası, eklemeler, bebek aracılı, çoklu şema sırası, sosyodramatik oyun, tematik hayali oyun seviyesi puanları 
ile Beklenmeyen Yer değiştirme, Görünüm Gerçeklik ve Yanlış Kanı Atfı puanları arasında istatistiksel açıdan Tablo 6'da görüldüğü gibi anlamlı bir ilişki olduğu ve bu ilişkinin şiddetinin sırasıyla orta ve yüksek düzeyde olduğu görülmektedir.

Farklı Görme Düzeylerine Göre Katılımcıların Gelişimsel Oyun Seviyeleri ve Yanlış Kanı Atfı Puanlarının İlişkisinin İncelenmesi

Araştırmada ağır görme yetersizliği olan çocuklar, az gören çocuklar ve gören çocukların gelişimsel oyun seviyeleri puanları ile Zihin Kuramı Birinci Derece Yanlış Kanı Atfı puanları arasında anlamlı ilişkinin olup olmadığına dair istatistiksel açıdan ilişkinin belirlenmesi amacıyla yapılan Spearman Korelasyon testi sonuçları Tablo 7'de verilmiştir.

Tablo 7

Farklı Görme Düzeylerine Göre Çocukların Gelişimsel Oyun Seviyesi Puanları ile Birinci Derece Yanlış Kanı Atfi Puanlarinin Spearmen Korelasyon Analizi

\begin{tabular}{|c|c|c|c|c|c|c|c|c|c|c|c|c|c|}
\hline & & \multicolumn{3}{|c|}{$\begin{array}{c}\text { Beklenmeyen Yer } \\
\text { Değiştirme }\end{array}$} & \multicolumn{3}{|c|}{$\begin{array}{c}\text { Beklenmeyen } \\
\text { İçerik }\end{array}$} & \multicolumn{3}{|c|}{ Görünüm Gerçeklik } & \multicolumn{3}{|c|}{ Yanlış Kanı Atfı } \\
\hline & & $N$ & $r$ & $p$ & $N$ & $r$ & $p$ & $N$ & $r$ & $p$ & $N$ & $r$ & $p$ \\
\hline Ayrımsız oyun & $\begin{array}{c}\text { AGYO } \\
\text { AG } \\
\text { G }\end{array}$ & $\begin{array}{l}11 \\
19 \\
30\end{array}$ & $\begin{array}{l}-.36 \\
-.113 \\
-.06\end{array}$ & $\begin{array}{l}.267 \\
.645 \\
.747\end{array}$ & $\begin{array}{l}11 \\
19 \\
30\end{array}$ & $\begin{array}{l}-.22 \\
-.14 \\
-.11\end{array}$ & $\begin{array}{l}.509 \\
.545 \\
.953\end{array}$ & $\begin{array}{l}11 \\
19 \\
30\end{array}$ & $\begin{array}{l}.064 \\
-.22 \\
.14\end{array}$ & $\begin{array}{l}.852 \\
.365 \\
.447\end{array}$ & $\begin{array}{l}11 \\
19 \\
30\end{array}$ & $\begin{array}{l}-.17 \\
-.25 \\
.05\end{array}$ & $\begin{array}{l}.605 \\
.291 \\
.756\end{array}$ \\
\hline Ayrımlı oyun & $\begin{array}{c}\text { AGYO } \\
\text { AG } \\
\text { G }\end{array}$ & $\begin{array}{l}11 \\
19 \\
30\end{array}$ & $\begin{array}{l}-.58 \\
-.06 \\
-.04\end{array}$ & $\begin{array}{l}.061 \\
.785 \\
.809\end{array}$ & $\begin{array}{l}19 \\
19 \\
30\end{array}$ & $\begin{array}{l}-.35 \\
-.35 \\
-.18\end{array}$ & $\begin{array}{l}.290 \\
.139 \\
.341\end{array}$ & $\begin{array}{l}19 \\
19 \\
30\end{array}$ & $\begin{array}{l}.06 \\
.26 \\
.14\end{array}$ & $\begin{array}{l}.852 \\
.279 \\
.447\end{array}$ & $\begin{array}{l}11 \\
19 \\
30\end{array}$ & $\begin{array}{l}-.49 \\
-.14 \\
.01\end{array}$ & $\begin{array}{l}.118 \\
.557 \\
.959\end{array}$ \\
\hline $\begin{array}{l}\text { Birleşimleri } \\
\text { parçalarına } \\
\text { ayırma }\end{array}$ & $\begin{array}{c}\text { AGYO } \\
\text { AG } \\
\text { G }\end{array}$ & $\begin{array}{l}11 \\
19 \\
30\end{array}$ & $\begin{array}{l}.06 \\
.11 \\
.01\end{array}$ & $\begin{array}{l}.842 \\
.632 \\
.939\end{array}$ & $\begin{array}{l}11 \\
19 \\
30\end{array}$ & $\begin{array}{c}-.28 \\
-.13 \\
.01\end{array}$ & $\begin{array}{l}.395 \\
.132 \\
.933\end{array}$ & $\begin{array}{l}11 \\
19 \\
30\end{array}$ & $\begin{array}{l}-.28 \\
-.31 \\
.00\end{array}$ & $\begin{array}{l}.395 \\
.190 \\
.123\end{array}$ & $\begin{array}{l}11 \\
19 \\
30\end{array}$ & $\begin{array}{l}-.16 \\
-.08 \\
.02\end{array}$ & $\begin{array}{l}.630 \\
.745 \\
.903\end{array}$ \\
\hline $\begin{array}{l}\text { Görünüm } \\
\text { birleşimleri }\end{array}$ & $\begin{array}{c}\text { AGYO } \\
\text { AG } \\
\text { G }\end{array}$ & $\begin{array}{l}11 \\
19 \\
30\end{array}$ & $\begin{array}{l}.30 \\
.17 \\
.05\end{array}$ & $\begin{array}{l}.357 \\
.467 \\
.795\end{array}$ & $\begin{array}{l}11 \\
19 \\
30\end{array}$ & $\begin{array}{l}.21 \\
.32 \\
.17\end{array}$ & $\begin{array}{l}.527 \\
.170 \\
.349\end{array}$ & $\begin{array}{l}11 \\
19 \\
30\end{array}$ & $\begin{array}{l}.03 \\
.13 \\
-.04\end{array}$ & $\begin{array}{l}.917 \\
.595 \\
.807\end{array}$ & $\begin{array}{l}11 \\
19 \\
30\end{array}$ & $\begin{array}{l}.29 \\
.36 \\
.05\end{array}$ & $\begin{array}{l}.378 \\
.122 \\
.770\end{array}$ \\
\hline $\begin{array}{l}\text { Genel } \\
\text { birleşimler }\end{array}$ & $\begin{array}{c}\text { AGYO } \\
\text { AG } \\
\text { G }\end{array}$ & $\begin{array}{l}11 \\
19 \\
30\end{array}$ & $\begin{array}{l}-.20 \\
-.07 \\
.07\end{array}$ & $\begin{array}{l}.545 \\
.977 \\
.681\end{array}$ & $\begin{array}{l}11 \\
19 \\
30\end{array}$ & $\begin{array}{c}.03 \\
.41 \\
-.09\end{array}$ & $\begin{array}{l}.917 \\
.074 \\
.633\end{array}$ & $\begin{array}{l}11 \\
19 \\
30\end{array}$ & $\begin{array}{l}.53 \\
.26 \\
-.14\end{array}$ & $\begin{array}{l}.090 \\
.270 \\
.438\end{array}$ & $\begin{array}{l}11 \\
19 \\
30\end{array}$ & $\begin{array}{l}.13 \\
.38 \\
.06\end{array}$ & $\begin{array}{l}.701 \\
.102 \\
.725\end{array}$ \\
\hline $\begin{array}{l}\text { Kendini } \\
\text { sembolize } \\
\text { etme }\end{array}$ & $\begin{array}{c}\text { AGYO } \\
\text { AG } \\
\text { G }\end{array}$ & $\begin{array}{l}11 \\
19 \\
30\end{array}$ & $\begin{array}{l}.15 \\
-.13 \\
.18\end{array}$ & $\begin{array}{l}.642 \\
.584 \\
.320\end{array}$ & $\begin{array}{l}11 \\
19 \\
30\end{array}$ & $\begin{array}{l}.56 \\
.32 \\
.09\end{array}$ & $\begin{array}{l}.072 \\
.175 \\
.922\end{array}$ & $\begin{array}{l}11 \\
19 \\
30\end{array}$ & $\begin{array}{l}.26 \\
.38 \\
.33\end{array}$ & $\begin{array}{l}.432 \\
.103 \\
.074\end{array}$ & $\begin{array}{l}11 \\
19 \\
30\end{array}$ & $\begin{array}{l}.42 \\
.12 \\
.20\end{array}$ & $\begin{array}{l}.192 \\
.605 \\
.275\end{array}$ \\
\hline $\begin{array}{l}\text { Özel } \\
\text { birleşimler }\end{array}$ & $\begin{array}{c}\text { AGYO } \\
\text { AG } \\
\text { G }\end{array}$ & $\begin{array}{l}11 \\
19 \\
30\end{array}$ & $\begin{array}{c}-.35 \\
-.13 \\
.06\end{array}$ & $\begin{array}{l}.284 \\
.584 \\
.745\end{array}$ & $\begin{array}{l}11 \\
19 \\
30\end{array}$ & $\begin{array}{l}.16 \\
.32 \\
.39\end{array}$ & $\begin{array}{l}.628 \\
.175 \\
.033\end{array}$ & $\begin{array}{l}11 \\
19 \\
30\end{array}$ & $\begin{array}{l}.53 \\
.38 \\
-.16\end{array}$ & $\begin{array}{l}.089 \\
.103 \\
.389\end{array}$ & $\begin{array}{l}11 \\
19 \\
30\end{array}$ & $\begin{array}{l}.18 \\
.33 \\
-.19\end{array}$ & $\begin{array}{l}.577 \\
.162 \\
.292\end{array}$ \\
\hline Çocuk aracılı & $\begin{array}{c}\text { AGYO } \\
\text { AG } \\
\text { G }\end{array}$ & $\begin{array}{l}11 \\
19 \\
30\end{array}$ & $\begin{array}{l}.34 \\
.49 \\
.07\end{array}$ & $\begin{array}{l}.022^{*} \\
.030^{*} \\
.691\end{array}$ & $\begin{array}{l}11 \\
19 \\
30\end{array}$ & $\begin{array}{l}.43 \\
.208 \\
.11\end{array}$ & $\begin{array}{l}.177 \\
.392 \\
.561\end{array}$ & $\begin{array}{l}11 \\
19 \\
30\end{array}$ & $\begin{array}{l}.55 \\
.35 \\
.03\end{array}$ & $\begin{array}{l}.030^{*} \\
.013^{*} \\
.837\end{array}$ & $\begin{array}{l}11 \\
19 \\
30\end{array}$ & $\begin{array}{l}.66 \\
.54 \\
.13\end{array}$ & $\begin{array}{l}.025 \\
.015 \\
.473\end{array}$ \\
\hline $\begin{array}{l}\text { Özel } \\
\text { birleşimler }\end{array}$ & $\begin{array}{c}\text { AGYO } \\
\text { AG } \\
\text { G }\end{array}$ & $\begin{array}{l}11 \\
19 \\
30\end{array}$ & $\begin{array}{c}.39 \\
.49 \\
-.03\end{array}$ & $\begin{array}{l}.032^{*} \\
.011^{*} \\
.836\end{array}$ & $\begin{array}{l}11 \\
19 \\
30\end{array}$ & $\begin{array}{c}.41 \\
.23 \\
-.06\end{array}$ & $\begin{array}{l}.904 \\
.338 \\
.752\end{array}$ & $\begin{array}{l}11 \\
19 \\
30\end{array}$ & $\begin{array}{c}.43 \\
.31 \\
-.04\end{array}$ & $\begin{array}{l}.023^{*} \\
.024^{*} \\
.833\end{array}$ & $\begin{array}{l}11 \\
19 \\
30\end{array}$ & $\begin{array}{c}.45 \\
.36 \\
-.03\end{array}$ & $\begin{array}{l}.038 \\
.027 \\
.866\end{array}$ \\
\hline Tek şema sırası & $\begin{array}{c}\text { AGYO } \\
\text { AG } \\
\text { G }\end{array}$ & $\begin{array}{l}11 \\
19 \\
30\end{array}$ & $\begin{array}{l}.34 \\
.52 \\
.07\end{array}$ & $\begin{array}{l}.024^{*} \\
.022^{*} \\
.677\end{array}$ & $\begin{array}{l}11 \\
19 \\
30\end{array}$ & $\begin{array}{l}.53 \\
.31 \\
.08\end{array}$ & $\begin{array}{l}.090 \\
.183 \\
.644\end{array}$ & $\begin{array}{l}11 \\
19 \\
30\end{array}$ & $\begin{array}{l}.42 \\
.44 \\
.32\end{array}$ & $\begin{array}{l}.033^{*} \\
.041^{*} \\
.078\end{array}$ & $\begin{array}{l}11 \\
19 \\
30\end{array}$ & $\begin{array}{l}.40 \\
.39 \\
.16\end{array}$ & $\begin{array}{l}.033 \\
.022 \\
.395\end{array}$ \\
\hline Eklemeler & $\begin{array}{c}\text { AGYO } \\
\text { AG } \\
\text { G }\end{array}$ & $\begin{array}{l}11 \\
19 \\
30\end{array}$ & $\begin{array}{l}.49 \\
.44 \\
.33\end{array}$ & $\begin{array}{l}.022^{*} \\
.047^{*} \\
.045^{*}\end{array}$ & $\begin{array}{l}11 \\
19 \\
30\end{array}$ & $\begin{array}{c}.31 \\
.31 \\
-.08\end{array}$ & $\begin{array}{l}.351 \\
.183 \\
.642\end{array}$ & $\begin{array}{l}11 \\
19 \\
30\end{array}$ & $\begin{array}{l}.47 \\
.42 \\
.30\end{array}$ & $\begin{array}{l}.043^{*} \\
.031^{*} \\
.045^{*}\end{array}$ & $\begin{array}{l}11 \\
19 \\
30\end{array}$ & $\begin{array}{l}.53 \\
.60 \\
.40\end{array}$ & $\begin{array}{l}.011 \\
.006 \\
.020\end{array}$ \\
\hline Bebek aracilı & $\begin{array}{c}\text { AGYO } \\
\text { AG } \\
\text { G }\end{array}$ & $\begin{array}{l}11 \\
19 \\
30\end{array}$ & $\begin{array}{l}.39 \\
.34 \\
.38\end{array}$ & $\begin{array}{l}.032^{*} \\
.015^{*} \\
.035^{*}\end{array}$ & $\begin{array}{l}11 \\
19 \\
30\end{array}$ & $\begin{array}{l}.34 \\
.23 \\
.18\end{array}$ & $\begin{array}{l}.063 \\
.155 \\
.316\end{array}$ & $\begin{array}{l}11 \\
19 \\
30\end{array}$ & $\begin{array}{l}.38 \\
.53 \\
.32\end{array}$ & $\begin{array}{l}.024^{*} \\
.019^{*} \\
.048^{*}\end{array}$ & $\begin{array}{l}11 \\
19 \\
30\end{array}$ & $\begin{array}{l}.63 \\
.62 \\
.44\end{array}$ & $\begin{array}{l}.034 \\
.004 \\
.014\end{array}$ \\
\hline $\begin{array}{l}\text { Çoklu şema } \\
\text { sırası }\end{array}$ & $\begin{array}{c}\text { AGYO } \\
\text { AG } \\
\text { G }\end{array}$ & $\begin{array}{l}11 \\
19 \\
30\end{array}$ & $\begin{array}{c}.49 \\
.48 \\
.38^{*}\end{array}$ & $\begin{array}{l}.043^{*} \\
.034^{*} \\
.036^{*}\end{array}$ & $\begin{array}{l}11 \\
19 \\
30\end{array}$ & $\begin{array}{l}.52 \\
.18 \\
.27\end{array}$ & $\begin{array}{l}.094 \\
.452 \\
.141\end{array}$ & $\begin{array}{l}11 \\
19 \\
30\end{array}$ & $\begin{array}{l}.34 \\
.48 \\
.37\end{array}$ & $\begin{array}{l}.044^{*} \\
.035^{*} \\
.042^{*}\end{array}$ & $\begin{array}{l}11 \\
19 \\
30\end{array}$ & $\begin{array}{l}.72 \\
.58 \\
.49\end{array}$ & $\begin{array}{l}.011 \\
.009 \\
.005\end{array}$ \\
\hline
\end{tabular}


Tablo 7 (devami)

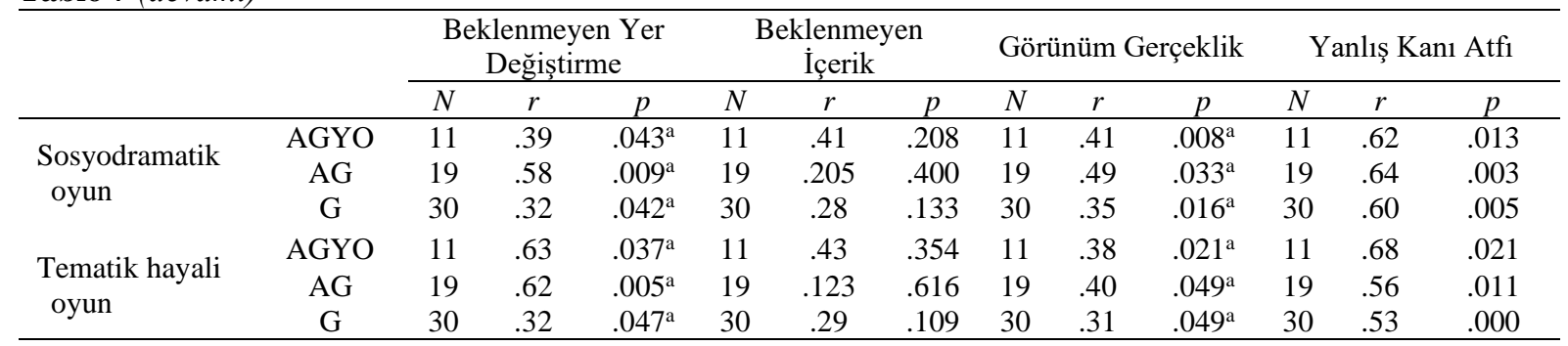

Not: $\mathrm{AGYO}=$ ağır görme yetersizliği, $\mathrm{AG}=$ az gören, $\mathrm{G}=$ gören .

Ağır görme yetersizliği olan çocukların gelişimsel oyun seviyeleri olan çocuk aracılı, özel birleşimler, tek şema sırası, eklemeler, bebek aracılı, çoklu şema sırası, sosyodramatik oyun, tematik hayali oyun seviyesi puanları ile yanlış kanı atfı puanları, Beklenmeyen Yer Değiştirme ve Görünüm Gerçeklik puanları arasında istatistiksel açıdan anlamlı bir ilişki Tablo 7'de görüldüğü gibi orta ve yüksek düzeyde olduğu görülmektedir. Az gören çocukların da gelişimsel oyun seviyeleri olan çocuk aracılı, özel birleșimler, tek şema sırası, eklemeler, bebek aracılı, çoklu şema sırası, sosyodramatik oyun, tematik hayali oyun seviyesi puanları ile Yanlış Kanı Atfı puanları, Beklenmeyen Yer Değiştirme ve Görünüm Gerçeklik puanları arasında istatistiksel açıdan anlamlı bir ilişki Tablo 7'de görüldüğü gibi orta ve yüksek düzeyde olduğu görülmektedir. Ayrıca gören çocukların gelişimsel oyun seviyeleri olan eklemeler, bebek aracılı, çoklu şema sırası, sosyodramatik oyun, tematik hayali oyun seviyesi puanları ile Yanlış Kanı Atfı puanları arasında istatistiksel açıdan Tablo 7'de görüldüğü gibi anlamlı bir ilişki olduğu ve bu ilişkinin şiddetinin sırasıyla orta ve yüksek düzeyde olduğu görülmektedir.

\section{Tartışma}

Yapılan araştırmada yaşları 48 ila 72 ay arasında değişen, dil bilişsel alanda gelişimsel gecikmesi olamayan veya ek yetersizliği olmayan, görme yetersizliği olan ve gören çocukların gelişimsel oyun seviyeleri karşılaştırılmış ve gelişimsel oyun seviyeleri ile yanlış kanı atfı puanları arasındaki ilişkiler incelenmiştir. Araştırmanın birinci amacı kapsamında dil-bilişsel gelişim yaşları eşitlenen iki katılımcı grubunun gelişimsel oyun seviyeleri arasında fark olup olmadığı incelenmiştir. Yapılan analizler sonucunda görme yetersizliği olan ve gören çocukların çoklu şema sırası, sosyodramatik oyun ve tematik hayali oyun seviyelerinde istatistiksel açıdan anlamlı farklılıklar gösterdikleri bulgulanmıştır. Çocuğun oyun sırasında aynı bebekle farklı eylemleri gerçekleştirdiği ve oyunundaki davranışlarını bir nesne ile çeşitlendirdiği çoklu şema sırası seviyesinde, görme yetersizliği olan çocukların puanları, gören çocukların puanlarına göre anlamlı düzeyde düşük çıkmıştır. Bu oyun aşaması, bebeğe yemek yedirme, bebeğin saçını tarama, bebeğe su içirme, bebeğe oyun oynattırma gibi bir figürle farklı eylemler yapma oyun davranışlarını içermektedir. Araştırmada görme yetersizliği olan çocukların oyun davranışlarının sıklığı ve tür sayısı çoklu şema seviyesinde incelendiğinde de gören akranlarına göre anlamlı düzeyde düşük çeşitlilikte oyun tür ve çeşitliliği sergiledikleri saptanmıştır. Araştırmanın bulguları ile alanyazındaki araştırma sonuçları karşılaştırıldığında örneğin Aslan ve diğerlerinin (2015) görme yetersizliği olan çocuklar ile gören çocukların oyun davranışlarındaki çeşitliliği ve karmaşıklık düzeyini inceledikleri bir çalışmada görme yetersizliği olan çocukların gören akranlarına göre sınırlı çeşitlilikte oyun davranışları sergilediklerini rapor ettikleri ve görme yetersizliği olan çocukların oyunlarının da genel olarak aynı oyun davranışlarının tekrarı niteliğinde olduğunu dikkat çekmektedir. Alanyazında pek çok araştırmacı görme yetersizliği olan çocukların tekrarlayıcı oyunlar oynadıklarını ve oyun niteliklerinde gören akranları ile anlamlı farklılıkların saptandığını rapor etmişlerdir (Bishop vd., 2005; Lewis vd., 2000; Şahin \& Özdemir, 2015). Bu araştırmanın bulguları ise görme yetersizliği olan çocukların oyun düzeylerinin daha çok sembolik oyun aşamasında gören akranlarından farklılaştığını göstermekle birlikte, görme yetersizliği olan çocukların oyun düzeylerinin gören akranlarından açık olarak farklılaştığına işaret etmektedir. Üstelik yapılan bu çalışmada görme yetersizliği olan ve gören katılımcıların dil-bilişsel gelişimleri eşitlenmiştir. Oysaki pek çok araştırmada katılımcı çocuklar ve karşılaştırma grupları arasında dil-bilişsel gelişim denkliğine yönelik açık bilgiye yer verilmediği veya denkliğin rapor edilmediği görülmektedir (Ferguson \& Buulltjens, 1995; Tröster \& Brambring, 1991).

$\mathrm{Bu}$ araştırma kapsamında katılımcı çocukların farklı görme düzeylerine göre, gören akranları ile karşılaştırıldığında elde edilen bulgularda ise ağır görme yetersizliği olan çocukların, az gören ve gören akranlarına göre çoklu şema sırası seviyesinde istatiksel açıdan anlamlı farklılıklar gösterdikleri saptanmıştır. Araştırmada ağır görme yetersizliği olan çocuklar az gören ve gören çocukların puanlarına göre anlamlı düzeyde düşük puanlar almışlardır. Pek çok araştırmacı da bu araştırmada olduğu gibi görme düzeylerinin oyun davranışlarında 
farklılıklar ortaya çıkardığını ve ağır görme yetersizliği olan çocukların az gören çocuklara göre daha yüksek düzeyde risk sergilediklerini rapor etmişlerdir (Aslan vd., 2015; Moller, 1991; Parsons, 1986; Recchia, 1987; Şahin \& Özdemir, 2015). Ancak yukarıda vurgulandığı gibi bu araştırmada dil bilişsel gelişim denkliği sağlanan üç grup arasında ağır görme yetersizliği olan çocukların sergiledikleri farklılıklar bu grupta yer alan çocukların oyun davranışları gelişimi üzerine görmenin etkisine ilişkin açık bilgi sağlamaktadır.

Araştırma bulgularında saptanan bir diğer farklılık ise sosyodramatik oyun seviyesinde gözlemlenen farklılıktır. Sosyodramatik oyun seviyesinde görme yetersizliği olan çocukların oyun puanlarının gören çocukların oyun puanlarına göre düşük olduğu görülmüştür. Sosyodramatik oyun seviyesi çocukların günlük yaşam deneyimlerinin canlandırıldığı gözlem ve taklide yoğun olarak yer verilen bir oyun seviyesi olarak ele alınmaktadır (Howes vd., 1989). Bu oyun seviyesinde çocuklar bir karakterin rollerini canlandırarak, bir oyun teması etrafında örüntülenen hayali bir oyunu sergilemektedirler. Sosyodramatik oyun seviyesinde görme düzeylerine göre yapılan analizlerde de üç grup arasında istatistiksel açıdan anlamlı farklılıklar bulgulanmış, ağır görme yetersizliğinden etkilenmiş olan çocukların az gören ve gören çocukların puanlarına göre çok daha düşük puanlar aldıkları saptanmıştır. Alanyazında da farklı araştırmacılar tarafından görme yetersizliği olan çocuklarda görsel bilgi sınırlılığı veya yoksunluğunun diğer bir ifade ile sosyal ve fiziksel çevreyi izleme sınırlılığının çocukların oyunlarında gecikmelere neden olabileceğini belirtilmektedir (Fewell \& Kaminski, 1988; Moller, 1991; Recchia, 1987; Skellenger \& Hill, 1994).

Gören çocuklar oyunlarında günlük yaşam deneyimlerine sıklıkla yer vererek toplumsal rolleri canlandırmaktadırlar. Bu bağlamda çocuklar özellikle ebeveynlerini ve çevrelerini gözlemleyerek oyunlarında gözlemledikleri rolleri taklit etmektedirler. Görme yetersizliği olan çocukların görsel bilgi sınırlılıkları nedeniyle oyunlarında bu rolleri almakta sınırlılık sergileyebilecekleri farklı araştırmacılar tarafından da tartışılmaktadır (Ferguson \& Buulltjens, 1995; Parsons, 1986; Pizzo \& Bruce, 2010; Preisler, 1993). Örneğin Andersen ve diğerleri (1984) görme yetersizliği olan çocukların oyunlarında hayali oyun davranışlarının ya sınırlı düzeyde gözlemlendiğini veya hiç gözlemlenmediğini rapor etmişlerdir. Öte yandan ağır görme yetersizliğinden etkilenmiş çocukların yaşantı sınırlılıklarının da diğer bir ifadeyle günlük yaşama yaparak yaşayarak aktif olarak katılma fırsatlarının da çocuğun çevresi tarafından sınırlandırılmasının, çocukların oyun gelişimleriyle beraber, birçok gelişimsel becerilerini de olumsuz etkileyebileceği tartışılmaktadır.

Yapılan bu çalışmada bir diğer seviye olan tematik hayali oyun seviyesinde de görme yetersizliği olan ve gören çocukların puanları karşılaştırıldığında istatistiksel açıdan anlamlı farklılıklar saptanmıştır. Tematik hayali oyun seviyesi Gelişimsel Oyun Değerlendirmesi Aracında en üst düzey oyun davranışlarına işaret etmektedir. Bu seviyede hayali bir karakteri veya bir çizgifilm karakterini çocuğun sergilediği oyun davranışlarında belirli bir tema doğrultusunda canlandırması beklenmektedir. Gören çocukların tematik hayali oyun seviyesi puanları görme yetersizliğinden etkilenmiş çocuklara göre anlamlı düzeyde yüksek çıkmıştır. Tematik hayali oyun seviyesinde görme düzeylerine göre değerlendirilen çocukların puanlarında üç grup arasında istatiksel açıdan anlamlı farklılıklar saptanmış, ağır görme yetersizliğinden etkilenmiş olan çocukların, az gören ve gören çocukların puanlarına göre daha düşük puanlar aldıkları bulgulanmıştır. Bu bulgu ise dil-bilişsel gelişim yaşları eşitlenen çocuklarda ağır görme yetersizliğinin üst düzey oyun sınırlılıkları ile ilişkili olduğunu göstermektedir. Singer ve Streiner de (1966) görme yetersizliği olan çocukların gözlemlerinin sınırlı veya hiç olmaması nedeniyle hayali oyunlarının da çok sınırlı düzeyde gözlemlendiğini rapor etmişlerdir. Ayrıca araştırmacılar doğuştan veya ağır görme yetersizliği olan çocukların hayali oyunlarının, az gören çocuklara göre de daha sınırlı düzeyde gözlendiğini belirtmişlerdir.

Bu araştırma kapsamında görme yetersizliği olan çocuklar ile gören çocuklarda sembolik oyun ve Zihin Kuramı ilişkisi her iki grup için ayrı ayrı değerlendirilmiştir. Oyunun gelişimsel sürecine vurgu yapan araştırmacılar (Lifter, 2008, Lifter, 2000) gelişimsel açıdan oyunun incelenmesini kritik ölçüde önemli olarak değerlendirmişlerdir. Yapılan birçok araştırmada oyun ve Zihin Kuramı ilişkisi tipik gelişim gösteren çocuklarda ve otizm spektrum bozukluğu olan çocuklarda incelenmiştir (Baron-Cohen \& Swettenham, 1997; Flavell vd., 1983; Leslie, 1987, 1992, 1994; Schwebel vd., 1999). Görme yetersizliği olan çocukların özellikle sembolik oyundaki sınırlılıklarının (Moller, 1991; Recchia, 1987; Skellenger \& Hill, 1994), sembolik düşünme ve sembolik dönüşümler ile ilişkisi göz önüne alındığında, görme düzeyinin oyun ve Zihin Kuramına etkileri görme yetersizliği olan çocukların gelişimlerinin daha iyi anlaşılması ve olası erken müdahale alanlarının belirlenmesinde dikkat çekmektedir. Nitekim çocuğun nesnelere atıfta bulunma veya bir nesneyi başka nesne yerine koyma davranışındaki gecikmenin, kendisi ve başkalarının istek ve niyetlerini anlamada da gecikmeler yaşamasıyla eş güdümlü olabieceği oyun ve Zihin Kuramı'nın ilişkisini inceleyen çalışmalarda ele alınmaktadır (Leslie, 1987; Lillard, 2017). 
Bu kapsamda bu araştırmadan elde edilen bulgular, görme yetersizliği olan çocukların Gelişimsel Oyun Değerlendirmesinde çocuk aracılı oyun seviyesi ile Yanlış Kanı Atfı toplam puanları arasında ilişki olduğunu göstermiştir. Hem ağır görme yetersizliği olan hem de az gören çocuklarda çocuk aracılı oyun seviyesini takip eden tüm üst seviye oyun aşamalarında da benzer ilişkiler tespit edilmiştir. Gören çocuklarda ise araştırma bulguları eklemeler oyun seviyesinden başlayarak, takip eden tüm oyun seviyeleri ve Zihin Kuramı yanlış kanı atfı puanı arasında ilişski olduğunu göstermiştir. Bu kapsamda görme yetersizliği olan ve gören çocukların sembolik oyun gelişimleri, gelişimsel oyun seviyeleri çerçevesinden değerlendirildiğinde katılımcı çocukların sembolik oyun gelişimleri ile beraber, yanlış kanı atfı görevlerinde başarılı oldukları tespit edilmiştir. Öyle ki bu araştırmadan elde edilen bulgular görme yetersizliği olan çocuklarda Zihin Kuramı Birinci Derece Yanlış Kanı Atfı ve gelişimsel oyun seviyesi ilişkisinin gören çocuklarla karşılaştırıldığında oyunun gelişimsel olarak daha erken sembolik oyun aşamalarıyla ilişkili olduğunu göstermektedir. Zihin Kuramı gelişimi ile anlamlı ilişkisi olduğu belirtilen sembolik oyunun çocuklarda oyun sırasında nesnelere atıfta bulunma ile temsil etme becerisini ortaya çıkardığı araştırmacılar tarafından vurgulanmaktadır (Leslie, 1994). Nitekim Newton ve Jenvey (2010) oyun becerileri ve Zihin Kuramı'na dair yaptıkları bir çalışmada sosyal oyun yeterliliklerinin Zihin Kuramı görev puanları ile eş güdümlü olarak farklılaştığını rapor etmişlerdir.

Özetle bu araştırmanın sonuçları, sembolik oyun gelişimininin Zihin Kuramı gelişimiyle ilişkisini vurgulayan alanyazındaki pek çok araştırmanın bulguları ile (Baron-Cohen \& Swettenham, 1997; Flavell vd., 1983; Leslie, 1987, 1992, 1994; Schwebel vd., 1999) tutarlılık göstermektedir. Görme yetersizliğinden etkilenmiș olan çocuklar oyunun tüm gelişim aşamalarının sıralandığı gelişimsel oyun seviyesi değerlendirmelerinde çoklu şema sırası, sosyodramatik oyun ve tematik hayali oyun seviyelerinde gören akranları ile anlamlı farklılıklar göstermemişlerdir. Ek bulgular, görme yetersizliği olan çocuklarda Gelişimsel Oyun Değerlendirmesi ile Zihin Kuramı ilişkisinin sembol öncesi oyun gelişiminde gözlendiği yönündedir.

Yapılan bu araştırma görme yetersizliği olan çocuklarda gelişimsel oyun düzeyi ve Zihin Kuramı arasındaki ilişkiyi ortaya koyan ilk araştırma olması açısıdan önemlidir. Çalışma hem Zihin Kuramı hem de gelişimsel oyun seviyesini etkileme potansiyelinde olan dil-bilişsel gelişim yaşının katılımcı çocuklar arasında denkliğinin sağlanması ile de sağladığı bilgiler açısından önemlidir. Bu sayede sadece görme yetersizliğinin oyun gelişimi ile ilişkisinin ve oyun gelişimi ile Zihin Kuramı arasındaki ilişkinin açık olarak anlaşılması mümkün olmuştur. Bu araştırmanın alanyazına sağladığı önemli katkıları ile beraber bazı sınırlılıkları da mevcuttur. İlk olarak araştırmada 48-72 ay aralığında bulunan toplam 60 katılımcı çocuğun gelişimsel oyun seviyeleri ve Zihin Kuramı Birinci Derece Yanlış Atfı becerileri arasındaki ilişkiler incelenmiştir. İleri araştırmalarda daha geniş örneklem grupları ile, sosyal etkileşim, duygusal yeterlilik, yürütücü işlevler gibi pek çok değişkenin görme yetersizliği olan çocuklarda oyun gelişimi ve Zihin Kuramı gelişimi üzerine etkileri derinlemesine incelenebilir. Öte yandan araştırmadan elde edilen pek çok bulgu da görme yetersizliği olan çocuklarda erken müdahale uygulamaları açısından önemli bilgiler içermektedir. Bu araştırmadan elde edilen bulgular, görme yetersizliği olan ve gören çocuklar arasında karmaşık oyun düzeylerinde farklılıklarının saptandığı yönündedir. Katılımcı çocuklar arasında dil bilişsel gelişim düzeylerinde farklılıklar gözlenmemesine karşın, oyun düzeyinde gözlemlenen farklılıklar, kaynaştırma eğitimine başlayacak olan görme yetersizliği olan çocukların gören akranlarıyla sosyalleşmede en önemli bağlamlarından olan ortak oyun etkileşimlerini etkileyebilecek niteliktedir. Bu kapsamda oyun müdahalelerinin önemi görme yetersizliği olan çocuklarda oyun müdahalelerine yer verilmesinin önemi anlaşılmaktadır. Nitekim çocukların oyun düzeyleri ile Zihin Kuramı Birinci Derece Yanlış Kanı Atfı arasında saptanan farklılıklar da özelikle sembolik oyun becerileri ile diğer bireylerin zihinsel süreçlerininin kişinin kişinin zihinsel süreçlerinden farklı olabileceğini anlama becerileri arasında ilişkiler yaşam boyu sosyal ilişkileri etkilebilecek potansiyeldedir. Bu kapsamda görme yetersizliği olan çocukların doğal sosyal yaşantılardan soyutlanmaması, zengin oyun ve sosyal etkileşim deneyimlerine maruz birakılması, erken müdahale programlarında da oyun ve Zihin Kuramı gelişimini destekleyici etkinliklere maruz bırakılması yaşam boyu sosyal uyumun desteklenmesinde ilk ve öncü müdahale alanları arasında dikkat çekmektedir.

\section{Yazarların Katkı Düzeyleri}

Araştırmanın planlama, uygulama, veri toplama süreçleri, analizleri, yazımı ve düzeltmeleri Seda Karakaşoğlu tarafından yapılmıştır. Araştırmanın yazımı ve düzeltmeleri Prof. Dr. Selda Özdemir'in katkıları ile tamamlanmıştır.

\section{Teşekkür}

Araştırmamıza katkı sunan ve çalışmalarımıza katılan tüm çocuklara ve ailelerine teşekkür ediyoruz. 


\section{Kaynaklar}

Andersen, E. S., Dunlea, A., \& Kekelis, L. S. (1984). Blind children's language: Resolving some differences. Journal of Child Language, 11(3), 645-664. http://doi.org/10.1017/S0305000900006000

Anghel, D. (2012). The development of theory of mind in children with congenital visual impairments. The Scientific Journal of Humanistic Studies, 4(7), 229-235.

Aslan, C., Özdemir, S., Demiryürek, P., \& Çotuk, H. (2015). Görme yetersizliğinden etkilenen ve normal gelişim gösteren çocukların oyun ç̧şitlilik ve karmaşıklık düzeylerinin incelenmesi [Examining play diversity and play complexity of typically developing children and children with visual impairments]. International Journal of Early Childhood Special Education, 7(2), 212-237.

Astington, J. W., \& Jenkins, J. M. (1999). A longitudinal study of the relation between language and theory-ofmind development. Developmental Psychology, 35(5), 1311.

Baron-Cohen, S. (2000). Understanding other minds: Perspectives from autism. In S. Baron-Cohen, H. TagerFlusberg, \& D. J. Cohen (Eds.), Theory of Mind and autism: A fifteen-year review (pp. 3-20). Oxford University.

Baron-Cohen, S., \& Swettenham, J. (1997). Theory of mind in autism: Its relationship to executive function and central coherence. In D. J. Cohen \& F. R. Volkmar (Eds.), Handbook of autism and pervasive developmental disorders (pp. 880-893). Wiley.

Bartoli, G., Bulgarelli, D., \& Molina, P. (2019). Theory of Mind development in children with visual impairment: The contribution of the adapted comprehensive test ToM storybooks. Journal of Autism and Developmental Disorders, 49(9), 3494-3503. http://doi.org/10.1007/s10803-019-04064-3

Baştuğ, S. (2016). Diyarbakır ilinde yaşayan görme yetersizliği olan çocuklarla normal gelişsim gösteren çocukların zihin kuramı becerileri ile yürütücü işlev becerilerinin karşılaştırılması [A comparision of theory of mind and executive functions in children with visual impairments and typically developing children living in Diyarbakır] (Tez Numarasi: 429535) [Yüksek lisans tezi, Gazi Üniversitesi]. Yükseköğretim Kurulu Ulusal Tez Merkezi.

Begeer, S., Dik, M., Voor De Wind, M. J., Asbrock, D., Brambring, M., \& Kef, S. (2014). A new look at theory of mind in children with ocular and ocular-plus congenital blindness. Journal of Visual Impairment \& Blindness, 108(1), 17-27. https://doi.org/10.1177/0145482X1410800103

Bigelow, A. E. (2003). The development of joint attention in blind infants. Development and Psychopathology, 15(2), 259-275. http://doi.org/10.1017/S0954579403000142

Billingsley, F., White, O. R., \& Munson, R. (1980). Procedural reliability: A rationale and an example. Behavioral Assessment, 2, 229-241.

Bishop, M., Hobson, R. P., \& Lee, A. (2005). Symbolic play in congenitally blind children. Development and Psychopathology, 17(2), 447-465. http://doi.org/10.1017/S0954579405050212

Brambring, M., \& Asbrock, D. (2010). Validity of false belief tasks in blind children. Journal of Autism and Developmental Disorders, 40(12), 1471-1484. https://doi.org/10.1007/s10803-010-1002-2

Brodsky, M. C., Fray, K. J., \& Glasier, C. M. (2002). Perinatal cortical and subcortical visual loss: Mechanisms of injury and associated ophthalmologic signs. Ophthalmology, 109(1), 85-94. http://doi.org/10.1016/s0161-6420(01)00849-1

Büyüköztürk, Ş., Kılıç-Çakmak, E., Akgün, Ö. E., Karadeniz, Ş., \& Demirel, F. (2008). Bilimsel araştırma yöntemleri [Scientific research methods]. Pegem.

Celeste, M. (2005). Impact of twin-to-twin transfusion syndrome, preterm birth and vision loss on development. Journal of Visual Impairment \& Blindness, 99(9), 535-548. https://doi.org/10.1177/0145482X0509900905

Demir, F. E., \& Özdemir, S. (2016a). A comparison of social skills of students with visual impairments and typically developing students. International E-Journal of Advances in Education, 2(4), 85-94. 
Demir, F. E., \& Özdemir, S. (2016b). A comparison of problem behaviors of students with visual impairments and typically developing students. International E-Journal of Advances in Education, 2(4), 122-131.

Erwin, E. J. (1993). Social participation of young children with visual impairments in specialized and integrated environments. Journal of Visual Impairment \& Blindness, 87(5), 138-142.

Fazzi, E., Signorini, S. G., Bova, S. M., La Piana, R., Ondei, P., Bertone, C., \& Bianchi, P. E. (2007). Spectrum of visual disorders in children with cerebral visual impairment. Journal of Child Neurology, 22(3), 294301. https://doi.org/10.1177/08830738070220030801

Ferguson, R., \& Buultjens, M. (1995). The play behaviour of young blind children and its relationship to developmental stages. British Journal of Visual Impairment, 13(3), 100-107.

Farrenkopf, C., \& Davidson, I. F. (1992). The development of perspective-taking abilities in young blind children. RE:view, 24(1), 7-22.

Fewell, R. R., \& Kaminski, R. (1988). Play skills development and instruction for young children with handicaps. Early Intervention for Infants and Children with Handicaps, 1,145-158.

Flavell, J. H. (2004). Theory-of-Mind development: Retrospect and prospect. Merrill-Palmer Quarterly, 50(3), 274-290. http://doi.org/10.1353/mpq.2004.0018

Flavell, J. H., Flavell, E. R., Green, F. L., \& Wilcox, S. A. (1983). The development of three spatial perspectivetaking rules. Child Development, 52, 356-358.

Flavell, J. H. (1992). Perspectives on perspective taking. In H. Beilin \& P. B. Pufall (Eds.), Piaget's theory: Prospects and possibilities (Vol. 14, pp. 107-139). Erlbaum.

Gerhardt, J. B. (1982). The development of object play and classificatory skills in a blind child. Journal of Visual Impairment and Blindness, 76(6), 219-23.

Green, S., Pring, L., \& Swettenham, J. (2004). An investigation of first-order false belief understanding of children with congenital profound visual impairment. British Journal of Developmental Psychology, 22(1), 1-17. http://doi.org/10.1348/026151004772901087

Hobson, R. P. (1990). On acquiring knowledge about people and the capacity to pretend: Response to Leslie (1987). Psychological Review, 97(1), 114-121. https://doi.org/10.1037/0033-295X.97.1.114

Howes, C., Unger, O., \& Seidner, L. B. (1989). Social pretend play in toddlers: Parallels with social play and with solitary pretend. Child Development, 60(1), 77-84. http://doi.org/10.2307/1131073

Huo, R., Burden, S. K., Hoyt, C. S., \& Good, W. V. (1999). Chronic cortical visual impairment in children: Aetiology, prognosis, and associated neurological deficits. British Journal of Ophthalmology, 83(6), 670675. http://doi.org/10.1136/bjo.83.6.670

Hull, T., \& Mason, H. (1995). A tactile version of the speed of information processing test for the blind-a revision and improvement. British Journal of Visual Impairment, 13(1), 33-36.

Işıtan, H. D., \& Özdemir, S. (2019). Görme yetersizliğinden etkilenmiş çocuklar ve gören çocukların Zihin Kuramı becerileri ile çalışma belleğinin karşılaştırılması [A comparison of the theory of mind and working memory performances of children with visual impairments and sighted children]. Hacettepe Üniversitesi Ĕ̈itim Fakültesi Dergisi, 35(4), 827-842. http://doi.org/10.16986/HUJE.2019055869

Kekelis, L. S. (1992). A field study of a blind preschooler. In S. Z. Sacks (Ed.), The development of social skills by blind and visually impaired students (pp. 39-58). AFB Press.

Leslie, A. M. (1987). Pretense and representation: The origins of theory of mind. Psychological Review, 94(4), $412-426$.

Leslie, A. M. (1992). Pretense, autism, and the theory-of-mind module. Current Directions in Psychological Science, 1(1), 18-21.

Leslie, A. M. (1994). Pretending and believing: Issues in the theory of ToMM. Cognition, 50(1-3), 211-238. 
Lewis, V., Norgate, S., Collis, G., \& Reynolds, R. (2000). The consequences of visual impairment for children's symbolic and functional play. British Journal of Developmental Psychology, 18(3), 449-464. http://doi.org/10.1348/026151000165797

Lifter, K. (2000). Linking assessment to intervention for children with developmental disabilities or at-risk for developmental delay: The Developmental Play Assessment (DPA) instrument. In K. Gitlin-Weiner, A. Sandgrund, \& C. Schafer (Eds.), Play diagnosis and assessment (2nd ed., pp. 228-261). John Wiley and Sons.

Lifter, K., \& Bloom, L. (1998). Intentionality and the role of play in the transition to language. In A. M. Wetherby, S. F. Warren, \& J. Reichle (Eds.), Transitions in prelinguistic communication: Preintentional to intentional and presymbolic to symbolic (pp. 161-198). Brookes.

Lillard, A. S. (2017). Why do the children pretend play? Trends in Cognitive Sciences, 21(11), 826-834.

McAlpine, L. M., \& Moore, C. L. (1995). The development of social understanding in children with visual impairments. Journal of Visual Impairment \& Blindness, 89(4), 349-358.

Minter, M., Hobson, R. P., \& Bishop, M. (1998). Congenital visual impairment and theory of mind. British Journal of Developmental Psychology, 16(2), 183-196.

Moller, M. A. (1991). The ophthalmologist's role with visually impaired children. Saunders.

Newton, E., \& Jenvey, V. (2010). Play and theory of mind: Associations with social competence in young children. Early Child Development and Care, 181(6), 761-773. http://doi.org/10.1080/03004430.2010.486898

Özdemir, S. (2016). Görme engellilerde erken çocukluk dönemi eğitimi: Görme engelli çocuklar ve özellikleri. Yayınlanmamış Yüksek Lisans Ders Notları. Gazi Üniversitesi, Ankara.

Özkubat, U., \& Özdemir, S. (2012). Görme yetersizliğinden etkilenmiş ve normal gelişim gösteren çocukların sosyal becerilerinin karşılaştırılması. Ankara Üniversitesi Eğitim Bilimleri Fakültesi Özel Eğitim Dergisi, 13(1), 1-14. https://doi.org/10.1501/Ozlegt_0000000163

Özkubat, U., \& Özdemir, S. (2014). A comparison of social skills in Turkish children with visual impairments, children with intellectual impairments and typically developing children. International Journal of Inclusive Education, 18(5), 500-514.

Parsons, S. (1986). Function of play in low vision children (Part 2): Emerging patterns of behavior. Journal of Visual Impairment \& Blindness, 80(6), 777-784.

Pijnacker, J., Vervloed, M., \& Steenbergen, B. (2012). Pragmatic abilities in children with congenital visual impairment: An exploration of non-literal language and advanced theory of mind understanding. Journal of Autism \& Developmental Disorders, 42(11), 2440-2449. https://doi.org/10.1007/s10803-012-1500-5

Pizzo, L., \& Bruce, S. M. (2010). Language and play in students with multiple disabilities and visual impairments or deaf-blindness. Journal of Visual Impairment \& Blindness, 104(5), 287-297. https://doi.org/10.1177/0145482X1010400504

Preisler, G. M. (1993). Blind children in nurseries with sighted children. International Journal of Rehabilitation Research, 16, 337-339.

Pring, L., Dewart, H., \& Brockbank, M. (1998). Social cognition in children with visual impairments. Journal of Visual Impairment \& Blindness, 92(11), 754-768.

Raz, N., Striem, E., Pundak, G., Orlov, T., \& Zohary, E. (2007). Superior serial memory in the blind: A case of cognitive compensatory adjustment. Current Biology, 17(13), 1129-1133. https://doi.org/10.1016/j.cub.2007.05.060

Recchia, S. L. (1987). Learning to play. Common concerns for the visually impaired preschool child. Blind Childrens's Center.

Recchia, S. L. (1997). Play and concept development in infants and young children with severe visual impairments: A constructivist view. Journal of Visual Impairment \& Blindness, 91(4), 401-416. 
Rettig, M. (1994). The play of young children with visual impairments: Characteristics and interventions. Journal of Visual Impairment \& Blindness, 88(5), 410-420.

Roch-Levecq, A. C. (2006). Production of basic emotions by children with congenital blindness: Evidence for the embodiment of theory of mind. British Journal of Developmental Psychology, 24(3), 507-528. https://doi.org/10.1348/026151005X50663

Rogers, S. J., \& Puchalski, C. B. (1984). Development of symbolic play in visually impaired young children. Topics in Early Childhood Special Education, 3(4), 57-63.

Ross, M. C. (2017). Promoting joint attention in children with visual impairment: Proposing an intervention using modified strategies from joint attention symbolic play engagement regulation (JASPER) [Doctoral dissertation, The Ohio State University]. https://eric.ed.gov/?id=ED584068

Rowland, C. (1984). Preverbal communication of blind infants and their mothers. Journal of Visual Impairment \& Blindness, 78(7), 297-302.

Röder, B., Rösler, F., \& Neville, H. J. (2001). Auditory memory in congenitally blind adults: A behavioralelectrophysiological investigation. Cognitive Brain Research, 11(2), 289-303.

Savaşır, I., Sezgin, N., \& Erol, N. (1993). Ankara Gelisim Tarama Envanteri [Ankara Developmental Screening Inventory]. Rekmay Yayınları.

Schwebel, D. C., Rosen, C. S., \& Singer, J. L. (1999). Preschoolers' pretend play and theory of mind: The role of jointly constructed pretence. British Journal of Developmental Psychology, 17(3), 333-348.

Singer, J. L., \& Streiner, B. F. (1966). Imaginative content in the dreams and fantasy play of blind and sighted children. Perceptual and Motor Skills, 22(2), 475-482.

Skellenger, A. C., \& Hill, E. W. (1994). Effects of a shared teacher-child play intervention on the play skills of three young children who are blind. Journal of Visual Impairment \& Blindness, 88(5), 433-445.

Swanson, H. L., \& Luxenberg, D. (2009). Short-term memory and working memory in children with blindness: Support for a domain general or domain specific system? Child Neuropsychology, 15(3), 280-294.

Şahin, R., \& Özdemir, S. (2015). Okul öncesi dönem görme engelli çocukların oyun çeşitlilik ve karmaşıklık düzeyini artırmada genişletme tekniğinin etkililiği [Effectiveness of play expansions in increasing play diversity and complexity of preschool children with visual impairments]. Ankara Üniversitesi Eğitim Bilimleri Fakültesi Özel Eğitim Dergisi, 16(02), 101-123. https://doi.org/10.1501/Ozlegt_0000000223

Tadić, V., Pring, L., \& Dale, N. (2010). Are language and social communication intact in children with congenital visual impairment at school age? Journal of Child Psychology and Psychiatry, 51(6), 696-705. https://doi.org/10.1111/j.1469-7610.2009.02200.x

Troster, H., \& Brambring, M. (1994). The play behavior and play materials of blind and sighted infants and preschoolers. Journal of Visual Impairment \& Blindness, 88(5), 421-432.

Warren, D. H. (1994). Blindness and children: An individual differences approach. Cambridge University Press.

Wellman, H. M. (2002). Understanding the psychological world: Developing a Theory of Mind. In U. Goswami (Ed.), Handbook of childhood cognitive development (pp. 167-187). Blackwell.

Wellman, H. M., Cross, D., \& Watson, J. (2001). Meta-analysis of Theory of Mind development: The truth about false belief. Child Development, 72(3), 655-684.

Wimmer, H., \& Perner, J. (1983). Beliefs about beliefs: Representation and constraining function of wrong beliefs in young children's understanding of deception. Cognition, 13, 103-128.

Wolery, M., Lane, K. L., \& Common, E. A. (2018). Writing Tasks: Literature reviews, research proposals, and final reports. In R. J. Ledford, \& D. Gast, (Eds.), Single case research methodology (pp. 74-126). Routledge.

World Health Organization. (2017). Change the defination of blindness. http://www.who.int/blindness/Change\%20the\%20Definition\%20of\%20Blindness.pdf 


\section{Ankara University Faculty of Educational Sciences Journal of Special Education}

2021, 22(3), 611-638
RESEARCH

Recieved Date: 15.04 .20

Accepted Date: 19.01.21

OnlineFirst: 31.01 .21

\title{
A Comparative Examination of Theory of Mind and Developmental Play Assessment in Children with Visual Impairments and Sighted Children*
}

\author{
Seda Karakaşoğlu $(i$
}

\author{
Selda Özdemir ${ }^{\text {iD } 2}$
}

\begin{abstract}
Introduction: This study examined the relationship between developmental play levels and theory of mind in children with visual impairments and sighted children during the preschool period.

Method: The study groups consisted of 30 children with visual impairments aged between 48-72 months and 30 age-matched sighted children. Participants in both groups were also matched to each other based on their cognitive and language levels. The design of the study was the comparative correlational design. The children's play levels were examined through the use of Developmental Play Assessment Tool developed by Lifter (2000) and FirstOrder False Belief Understanding tasks.

Findings: Study results showed that there were significant differences between the developmental play levels of children with visual impairments and sighted children. In addition, there was a significant relationship between children's first-order false-belief scores and developmental play assessment scores in all study groups.
\end{abstract}

Discussion: Findings from the study are important in understanding the development of vision, play, and theory of mind. Research findings were discussed and suggestions for future research were provided.

Keywords: Children with visual impairments, developmental play assessment, theory of mind, first-order falsebelief understanding, preschool period.

To cite: Karakaşoğlu, S., \& Özdemir, S. (2021). A comparative examination of theory of mind and developmental play assessment in children with visual impairments and sighted children. Ankara University Faculty of Educational Sciences Journal of Special Education, 22(3), 611-638. https://doi.org/10.21565/ozelegitimdergisi.719171

\footnotetext{
*This study was based on a master thesis of the first author under the supervision of Prof. Selda Ozdemir.

${ }^{1}$ Corresponded Author: Special Education Specialist, Istanbul Provincial Directorate of National Education, E-mail: sedakarakasoglu@gmail.com, https://orcid.org/0000-0002-3477-2389

${ }^{2}$ Prof., Hacettepe University, E-mail: seldaozdemir@hacettepe.edu.tr, https://orcid.org/0000-0001-9205-5946
} 


\section{Introduction}

Play is an enjoyable activity in which children actively discover the world around them. Lifter (2000) emphasizes that play has an important impact on children's development and has been found to be related to enriching children's knowledge about their environment. In fact, play enhances children's learning and cognitive development through supporting children's awareness of the social and physical world (Lifter \& Bloom, 1998). Piaget (1952) also believes that children actively discover the world around them through play and creating meaningful experiences with their environment (as cited by Fewell \& Glick, 1998).

Play has been widely accepted by many researchers in the field of education of children with visual impairments as crucial in children's development (Skellenger \& Hill, 1994). Even though, sighted children display active interactions with their environment using visual and auditory information effectively, children with visual impairments display difficulties in interacting with their social environment due to their limitations in visual information processing. Moreover, some researchers report that limitations in visual perception negatively affect these children's play behaviors and put them in risk for developing various developmental problems (Recchia, 1987; Warren, 1994). Previous observational studies also report that young children with visual impairments prefer toys that specifically provide auditory stimuli (Fewell \& Kaminski, 1988). Other researchers have found that children with visual impairments engage in more functional play behaviors than typically developing sighted controls (Celeste, 2005). Specifically, Recchia (1987) reported that children with visual impairments exhibit more repetitive play behaviors when engaged in object play than typically developing sighted controls. Furthermore, most children with visual impairments have been observed as playing alone during unstructured play times at schools (Fewell \& Kaminski, 1988).

Wellman (2002) described Theory of Mind (ToM) as a theory of the cognitive processes and an ability that people use in their daily lives for interpreting others' behaviors and mental states. ToM is a cognitive process that develops through gaining various developmental milestones such as imitation, joint attention, object permanence, social referencing, and symbolic thinking (Flavell, 2004). Potential developmental problems observed in the ToM understanding have been observed especially in children with autism spectrum disorders (ASD) or developmental delays (Baron-Cohen, 2000). In some ToM studies, researchers also reported that children with visual impairments received lower scores than their sighted peers (Begeer et al., 2014; Green et al., 2004; Hobson, 1990; McAlpine \& Moore, 1995; Minter et al., 1998; Recchia, 1997; Roch-Levecq, 2006). On the other hand, some researchers reported that children with visual impairments and sighted children had similar scores on ToM tasks (Anghel, 2012; Bartoli et al., 2019; Baştug, 2016; Isitan \& Ozdemir, 2018; Pijnacker et al., 2012).

There is a current discussion about how study variables may affect study results in the field of education and development of children with visual impairments. One important study variable that relates to research on children with visual impairments is the way that how children with visual impairments are matched to comparison groups. Even though matching participating children based on their language and/or cognitive levels has been very common in ToM literature, difficulties experienced in the assessment of language and cognitive skills of children with visual impairments using standardized measurements lead various problems. Most of the standardized instruments have many visual items and therefore using those instruments has not been accepted as a valid methodology in assessing children with visual impairments' language and/or cognitive levels. Furthermore, most studies lack of reporting proper validation of assessments related to additional developmental impairments in children with visual impairments. Another important problem in ToM studies conducted with children with visual impairments is related to children's vision levels and the time of their vision loss. Children with visual impairments have different levels of vision. Some children have severe visual impairments whereas some children have low vision. In addition, many children have some degree of vision at birth and lose their vision during their early childhood whereas some children do not have any vision at birth. An additional factor is that one of the most commonly diagnosed vision disorders in children with severe visual impairments is cerebral visual impairments (CVI). Children with CVI have frequently display additional impairments as their vision problems are caused by neurological damage. Thus, critical factors related to children's vision should be controlled in well-designed studies in other to provide a deeper understanding about the ToM and play development in children with visual impairments.

Overall, there is a critical need for well-designed research studies examining both the play skills and ToM understanding in children with visual impairments. Many of the previous studies report contradictory findings and 
synthesizing those research findings has been difficult due to the methodological limitations of the research studies. Thus, this study has two main purposes; first to examine the developmental play level differences between children with visual impairments and their sighted controls and second to explore the relationship between developmental play levels and First-Order False Belief Understanding in children with visual impairments and sighted children. The current study has four research questions:

1. Was there any difference between developmental play levels of children with visual impairments and sighted children?

2. Was there any difference between developmental play levels of children with low vision, children with severe visual impairments, and sighted children?

3. Was there any relationship between developmental play levels and First-Order False Belief Understanding in children with visual impairments and sighted children?

4. Was there any relationship between developmental play levels and First-Order False Belief Understanding in children with low vision, children with severe visual impairments, and sighted children?

\section{Method}

\section{Research Design}

A causal-comparative design was implemented to examine the relationship between developmental play levels and First-Order False Belief Understanding in pre-school children with visual impairments and sighted children. The causal-comparative design was used to explore potential causes of an existing problem or situation along with the variables affecting the problem or situation (Büyüköztürk et al., 2008).

\section{Participants}

A total of 30 children with visual impairments and 30 sighted children who lived in Istanbul and attended to preschools of Turkish Ministry of National Education participated in the study. Participants in both groups were matched to each other based on their cognitive and language levels and both groups did not display any cognitive and language delays.

Inclusion criteria were as follows for children with visual impairments; age between 48-72 months, having low vision or severe visual impairments diagnosis and not having any additional impairments and language and cognitive delays. Sighted participants were also between 48-72 months and had no developmental impairments or delays in the cognitive and language domains. Ankara Developmental Screening Inventory (ADSI) developed by Savaşır et al. (1993), was implemented to ensure that the participating groups were matched to each other. Oneon-one matching of children with visual impairments and sighted controls was performed based on children's cognitive and language scores.

\section{Data Collection Tools}

\section{Demographic Information Form}

A demographic information form was used to identify various demographic features of the families. The form was completed by the caregivers and included questions on children's chronological age, families' education and social economic status, clinical diagnosis of visual impairment, degree of visual loss, date of visual loss, and information related to children's education and development.

\section{Ankara Developmental Screening Inventory (ADSI)}

Ankara Developmental Screening Inventory (ADSI) developed by Savaşır et al., (1993) was filled with the information obtained from the parents (Savaşır et al., 1994). The findings of this study showed that children with visual impairments and their sighted peers showed no difference in their language and cognitive development $(p>.05)$.

\section{Developmental Play Assessment Tool}

The Developmental Play Assessment Tool (DPA) (Lifter, 2000) has been used to identify the developmental play levels of typically developing children and children with developmental delays. The DPA 
categorizes children's play under eight distinct play categories: 1) Indiscriminate Actions, 2a) Discriminative Actions, 2b) Takes Apart Combinations, 3a) Presentation Combinations, 3b) General Combinations, 3c) Pretend Self, 4) Specific Combinations, 5a) Child-as-Agent, 5b) Specific Conventional Combinations, 6a) Single Scheme Sequences, 6b) Substitutions, 7a) Doll as Agent, 7b) Multi-scheme Sequences, 8a) Socio-dramatic Play, 8b) Thematic/fantasy Play. The DPA was developed both to serve as an assessment instrument and a play curriculum.

\section{ToM-First-Order False Belief Reasoning Tasks}

The ToM, First-Order False Belief Understanding of the study participants were assessed using three different ToM categories. These tasks were Unexpected Location, Unexpected Content, and Appearance-Reality. A total of 6 implementations were carried out in the study. Each category were implemented with two different tasks. First-Order False Belief Understanding involves short stories that require a child's ability to interpret someone else's behavior and make inferences about the intent, belief, or thoughts of the story characters (Wimmer \& Perner, 1983). Even though this study implemented classical ToM tasks such as Sally-Anne Test (Baron-Cohen, 1987) and Smarties Test (Gopnik \& Astington, 1988), materials were initially tested with children with visual impairments via a pilot study to make sure that children with visual impairments have daily life experiences with the study materials. For example in one of the unexpected content tasks, a chewing gum box, commonly known by Turkish children was tested.

\section{Procedure}

In this study, the developmental levels of children were assessed using the Developmental Play Assessment (DPA) implementation procedures suggested by Lifter (2000). During the DPA assessment implementations, children seated on the carpeted floor with the first researcher seated in front of them. Two standard toy sets including a variety of toys appropriate to pretend play, functional play and combinational play were used to observe the children's play behaviors. During the ToM assessment, six different tasks were implemented with the all children. Real materials through hand over hand support were also used to assist children with visual impairments in exploring the tasks.

\section{Data Coding}

The developmental play levels of the study participants were coded by watching the prerecorded play behaviors of children and following DPA coding steps. Initially children's all play behaviors were transcribed. Following that, each play behavior's code category was defined and frequency of the play behaviors were counted. Thus, all children's play levels, play types and each play behavior's frequency were identified. Based on the DPA's coding rules, play behaviors were coded as absent (A) if a play behavior category has two and less play behavior examples, emergence (E) if a play behavior category has two types and four frequencies, and mastery (A) if a play behavior category has at least 4 types and 10 and more frequencies.

Data coding of the First-Order False Belief Understanding included coding of six different tasks under three categories, Unexpected Location, Unexpected Content, and Appearance-Reality. There were two questions per task. Thus, a maximum score of 12 was recorded when all questions answered correctly.

\section{Inter-Observer Reliability}

The inter-observer reliability was calculated to assess the agreement between two observers. $25 \%$ of the randomly selected DPI sessions and ToM sessions (including both groups) were coded by two observers for interobserver reliability. The inter-observer reliability for DPI was $86.7 \%$. The reliability of the Unexpected Location, Unexpected Content, and Appearance-Reality was $100 \%$ for each.

\section{Implementation Reliability}

The implementation reliability was calculated both for the DPI implementations and the ToM implementations. \%25 of the randomly selected DPI sessions and ToM sessions (including both groups) were coded for implementation reliability. The implementation reliability was $95.1 \%$ for DPI implementations. The reliability of First-Order False Belief Understanding, the Unexpected Location was 96.3\%, Unexpected Content was $96.1 \%$, and Appearance-Reality was $93.3 \%$ respectively. 


\section{Findings}

\section{Developmental Play Level Differences between Children with Visual Impairments and Sighted Children}

Study findings showed that there was a statistically significant difference $(p<.05)$ between the mean values of the multiple schema sequence level scores of children with visual impairments and sighted children. The effect size was $(r \geq .54)$ which was interpreted as a large effect $(r \geq .50)$. Similarly, a statistically significant difference $(p<.05)$ was found between the mean scores of the socio-dramatic play levels of the participating groups. The effect size $(r=.56)$ was high $(r \geq .50)$. There was a significant difference $(p<.05)$ between the thematic/fantasy play level scores of children with visual impairments and sighted children. The effect size of this difference between the two groups $(r=.55)$ was high $(r \geq .50)$.

\section{Developmental Play Level Differences among Children with Severe Visual Impairments, Children with Low Vision and Sighted Children}

Based on Kruskal Wallis results, study findings showed that there was a statistically significant difference ( $p<\alpha=.05$ ) between the multi-scheme sequence level scores of children with visual impairments, children with low vision and sighted children. Results also indicated that there was a statistically significant difference $(p=.00$ $<\alpha=.05$ ) between the socio-dramatic play level scores of children with visual impairments, children with low vision and sighted children. In addition, results showed that there was a statistically significant difference $(p=.00$ $<\alpha=.05)$ between the thematic/fantasy play scores of three groups.

Based on the post-hoc analysis, findings showed that there was a statistically significant difference $(p=$ $.00<\alpha=.05)$ in multi-scheme sequences, socio-dramatic play and thematic/fantasy play scores between children with severe visual impairments and sighted children. In addition, a statistically significant difference $(p=.00<\alpha$ $=.05$ ) was found between the multi-scheme sequences, socio-dramatic play and thematic/fantasy play scores of the children with low vision and sighted children.

\section{Correlation Analysis between Developmental Play Levels and Theory of Mind Scores in Children with Visual Impairments and Sighted Children}

A statistically significant relationship was found between the child-as-agent, specific conventional combinations, single schema sequences, substitutions, doll-as-agent, multi-schema sequences, socio-dramatic play, thematic/fantasy play scores and Unexpected Location scores of children with visual impairments $(p=.01<$ $.05, p=.04<.05, p=.01<.05, p=.04<.05, p=.01<.05, p=.00<.05, p=.00<.05, p=.00<.05)$ and overall the effect sizes of these relationships were medium $(r=52, r=.58, r=.60)$, and high $(r=.52, r=.58, r=.60)$ respectively. In addition, findings showed that there were statistically significant relationships between child-asagent, specific conventional combinations, single schema sequences, substitutions, doll-as-agent, multi-schema sequences, socio-dramatic play, thematic/fantasy play scores and Appearance-Reality scores of the children with visual impairments $(p=.02<.05, p=.02<.05, p=.04<.05, p=.00<.05, p=.00<.05, p=.00<.05, p=.00$ $<.05, p=.03<.05)$. Overall, the effect sizes of these relationships were found to be medium $(r=.41, r=.41, r=$ $.37, r=.48, r=.47, r=.48, r=.49, r=.38$ ) respectively. There were statistically significant relationships between substitutions, doll-as-agent, multi-scheme sequences, socio-dramatic play, thematic/fantasy play scores and Total First-Order False Belief Understanding scores of the sighted children $(p=.04<.05, p=.048<.05, p=.04<.05$, $p=.01<.05, p=.04<.05)$. The effect sizes of these relationships were medium $(r=.30, r=.32, r=.37, r=.35$, $r=.31)$ respectively.

Results indicated that there were statistically significant relationships between child-as-agent, specific conventional combinations, single schema sequences, substitutions, doll-as-agent, multi-schema sequences, sociodramatic play, thematic/fantasy play scores and Total First-Order False Belief Understanding of children with visual impairments $(p=.00<.05, p=.03<.05, p=.02<.05, p=.00<.05, p=.00<.05, p=.00<.05, p=.00$ $<.05, p=.00<.05)$ respectively. The effect size of this relationship was high $(r=.56)$, medium $(r=.34, r=.42)$, and high $(r=.55, \mathrm{r}=.59, r=.61, r=.64, r=.55)$ respectively. There were also statistically significant relationships between substitutions, doll-as-agent, multi-scheme sequences, socio-dramatic play, thematic/fantasy play scores and First-Order False Belief Understanding scores of the sighted children $(p=.02<.05, p=.01<.05, p=.00<$ $.05, p=.00<.05, p=.00<.05)$. The effect sizes of this relationship were medium $(r=.40, r=.44, r=.49)$ and high $(r=.60, r=.53)$ respectively. 


\section{Correlation Analysis between Developmental Play Levels and Theory of Mind Scores in Children with Severe Visual Impairments, Children with Low Vision, and Sighted Children}

Study findings showed that significant relationships were found between the child-as-agent, specific conventional combinations, single schema sequences, substitutions, doll-as-agent, multi-schema sequences, sociodramatic play, thematic/fantasy play scores and Unexpected Location scores of children with severe visual impairments $(p=.02<.05, p=.03<.05, p=.02<.05, p=.02<.05, p=.03<.05, p=.04<.05, p=.04<\alpha=$ $.05, p=.03<\alpha=.05)$. The effect sizes of these relationships were medium $(r=.34, r=.39, r=.34, r=.49, r=$ $.39 r=.49, r=.39)$ and high $(r=.63)$, respectively. Findings also showed that there were statistically significant relationships between the child-as-agent, specific conventional combinations, single schema sequences, substitutions, doll-as-agent, multi-schema sequences, socio-dramatic play, thematic/fantasy play scores and Unexpected Location scores of children with low vision $(p=.03<.05, p=.01<.05, p=.02<.05, p=.04<.05$, $p=.01<.05, p=.03<.05, p=.00<.05, p=.00<.05)$. The effect sizes of these relationships were medium $(r=$ $.49, r=.49, r=.44, r=.34, r=.48)$ and high $(r=.52, r=.58, r=.62)$ respectively.

Results showed that statistically significant relationships were observed between the child-as-agent, specific conventional combinations, single schema sequences, substitutions, doll-as-agent, multi-schema sequences, sociodramatic play, thematic/fantasy play scores and Appearance-Reality scores of children with severe visual impairments $(p=.03<.05, p=.02<.05, p=.03<.05, p=.04<.05, p=.02<.05, p=.04<.05, p=.00<\alpha=$ $.05, p=.02<\alpha=.05)$. The effect sizes of these relationships were medium $(r=.43, r=.42, r=.47, r=.38, r=$ $.34, r=.41, r=.38)$ and high $(r=.55)$ respectively. There were also statistically significant relationships between the child-as-agent, specific conventional combinations, single schema sequences, substitutions, doll-as-agent, multi-schema sequences, socio-dramatic play, thematic/fantasy play scores and Appearance-Reality scores of the children with low vision $(p=.013<.05, p=.024<.05, p=.041<.05, p=.031<.05, p=.019<.05, p=.035<$ $.05, p=.033<.05, p=.049<.05)$. The effect sizes of these relationships were medium $(r=.35, r=.31, r=.44$, $r=.42, r=.48, r=.49, r=.40)$ and high $(r=.53)$ respectively. Additionally, statistically significant relationships were identified between the substitutions, doll-as-agent, multiple schema sequences, specific conventional combinations, socio-dramatic play, thematic/fantasy play scores and First-Order False Belief Understanding scores of sighted children $(p=.045<.05, p=.048<.05, p=.042<.05, p=.016<.05, p=.049<.05)$. The effect sizes of these relationships were medium $(r=.30, r=.32, r=.37, r=.35, r=.31)$ respectively.

Lastly, statistically significant relationships were found between the child-as-agent, specific conventional combinations, single schema sequences, substitutions, doll-as-agent, multiple schema sequences, socio-dramatic play, thematic/fantasy play scores and First-Order False Belief Understanding scores of children with severe visual impairments $(p=.025<.05, p=.038<.05, p=.033<.05, p=.011<.05, p=.034<.05, p=.011<.05, p=.013$ $<.05, p=.021<.05)$. The effect sizes of these relationships were high $(r=.56)$, medium $(r=.45, r=.40)$, and high $(r=.66, r=.53, r=.63, r=.72, r=.62, r=.68)$ respectively. Study results also showed that there were statistically significant relationships between the child-as-agent, specific conventional combinations, single schema sequences, substitutions, doll-as-agent, multi-schema sequences, socio-dramatic play, thematic/fantasy play scores and First-Order False Belief Understanding scores of children with low vision $(p=.015<.05, p=.027$ $<.05, p=.022<.05, p=.006<.05, p=.004<\alpha=.05, p=.009<.05, p=.003<.05, p=.011<.05)$. The effect sizes of these relationships were high $(r=.56)$, medium $(r=.36, r=.39)$, and high $(r=.54, r=.60, r=.62, r=$ $.58, r=.64, r=.56$ ) respectively. Furthermore, statistically significant relationships were identified between the substitutions, doll-as-agent, multi-schema sequence, socio-dramatic play, thematic/fantasy play scores and FirstOrder False Belief Understanding scores of sighted children $(p=.020<.05, p=.014<.05, p=.005<.05, p=$ $.005<.05, p=.000<.05)$. The effect sizes of these relationships were medium $(r=.40, r=.44, r=.49)$ and high $(r=.60, r=.53)$ respectively.

\section{Discussion}

In this study, developmental play level differences between children with visual impairments and sighted children were explored. Study findings showed that there were statistically significant differences in multi-scheme sequences, socio-dramatic play, and thematic/fantasy play of children with visual impairments and sighted children. 
Considering the differences observed in the sociodramatic play level obtained in this study, one may consider that the socio-dramatic play levels are qualitatively related to children's daily life experiences. In this play level, children engage in symbolic play by using one object to represent another object and display a theme with different characters and different roles. Current literature suggests that limited daily life experiences of children with visual impairments in observing the social environment may cause delays in children's play (Fewell \& Kaminski, 1988; Moller, 1991; Recchia, 1987; Skellenger \& Hill, 1994). Findings from this study showed that children with severe visual impairments received significantly lower scores than those of children with low vision and sighted children. These findings suggest that limitations in visual perception about daily live experiences in children with severe visual impairments and children's limitations of active participation in daily life may affect children's play levels.

Significant differences were also observed between the thematic/fantasy play scores of children with visual impairments and sighted children. Thematic/fantasy play level represents the highest play level in the Developmental Play Assessment Tool. At this level, children are expected to imitate roles of a cartoon or an imaginary character around a theme. The scores of the thematic/fantasy play of the sighted children were significantly higher than children with visual impairments. More specifically, children with severe visual impairments received much lower scores than children with low vision and sighted children within thematic/fantasy play level. Although there is a limited number of studies on the play development of children with visual impairments, Andersen et al. (1984) found that thematic/fantasy play were either observed to a limited extent or not observed in the play development of children with visual impairments. These findings suggest that children with severe visual impairments display higher levels of limitations in their symbolic play development. Singer and Streiner (1966) reported that the thematic/fantasy play scores of children with visual impairments were very limited due to their limited visual observations. These researchers also reported that the thematic/fantasy play scores of children with congenital or severe visual impairments were lower than children with low vision.

This study has also explored the correlations between symbolic play development and First Order False Belief Understanding in two groups, children with visual impairments and sighted children. Study findings showed that there was a relationship between the child-as-agent play level and First-Order False Belief Understanding in children with visual impairments. Similar correlations were also found in more advanced level play levels in both children with severe visual impairments and children with low vision. In sighted children, on the other hand, research findings showed that there were correlations between children's play levels and First-Order False Belief Understanding scores beginning from the substitutions play level. Overall, current study findings showed that First-Order False Belief Understanding were closely related to symbolic play development in all study groups. More specifically, First-Order False Belief Understanding was found to be associated with pre-symbolic play behaviors in children with visual impairments. In fact, researchers address that symbolic play in young children is a clear indicator of the ability to represent objects symbolically during play (Leslie, 1994).

Overall, the results of this study are consistent with the findings of the current literature showing the relationship between development of symbolic play and Theory of Mind understanding (Leslie, 1987; Roth, 2002). Children with visual impairments displayed significant differences in multi-scheme sequences, socio-dramatic play and thematic/fantasy play when compared to their sighted peers. The development of First-Order False Belief Understanding has been widely linked to pre-symbolic play development in the current literature (Baron-Cohen \& Swettenham, 1997). Findings also showed a clear relationship between developmental play levels and FirstOrder False Belief Understanding of children with visual impairments.

\section{Author's Contributions}

Seda Karakaşoğlu designed, coordinated, implemented the study experiments, carried out data collection and data analysis, reported the results, wrote and edited the manuscript. Dr. Özdemir wrote, reviewed, and edited the manuscript.

\section{Acknowledgment}

We would like to thank all children and their parents who contributed to our study. 